\title{
Vključevanje rezultatov ocene tveganja zaradi izrednih vremenskih dogodkov v prostorsko načrtovanje elektroenergetske infrastrukture
}

V članku so obravnavani praktični ukrepi za vključevanje rezultatov ocene tveganja zaradi izrednih vremenskih dogodkov v postopek prostorskega načrtovanja. Na primerih ocene tveganja zaradi žleda za prenosno in distribucijsko elektroenergetsko omrežje ter za vetrne elektrarne je predstavljen postopek, ki vnaša rezultate ocene tveganja $\mathrm{v}$ analizo ustreznosti prostora. Najprej je izdelana ocena tveganja za prenosno in distribucijsko omrežje zaradi žleda. Rezultati ocene tveganja so uporabljeni kot podlaga za presojo predlaganih različic tras visokonapetostnega daljnovoda in kot vhodni podatek za analizo ustreznosti prostora za umestitev vetrnih elektrarn. Različici za umestitev vetrnih elektrarn $z$ upoštevanjem tveganja in brez tega smo primerjali z gospodarskega vidika in ugotovili, da lahko škode zaradi izrednih vremenskih dogodkov pomembno vplivajo na gospodarsko upravičenost načrta. Ugotavljamo, da lahko rezultate ocene tveganja na dva načina vključimo $\mathrm{v}$ načrtovanje elektroenergetske infrastrukture, in sicer s posodobitvijo inženirskih standardov in izogibanjem območjem, na katerih bi lahko nastale največje škode na infrastrukturi zaradi izrednih vremenskih dogodkov. Ocena tveganja je pomembna informacija, ki lahko vpliva na odločitve v zvezi z rabo prostora in tehničnimi ukrepi za povečanje odpornosti infrastrukture.

Ključne besede: prostorsko načrtovanje, ocena tveganja, izredni vremenski dogodki, energetska infrastruktura, ranljivost 


\section{Uvod}

Postopne podnebne spremembe $\mathrm{z}$ dvigom povprečnih temperatur in spremenjenim vzorcem padavin bodo vplivale na proizvodnjo ter potrebe in obseg rabe električne energije, najverjetneje pa tudi na njeno ceno, dostopnost in distribucijo (Feeley idr., 2008; Wilbanks idr., 2008; Kopytko in Perkins, 2011; Rübbelke in Vögele, 2011; McColl idr., 2012; Schaeffer idr., 2012). Izredni vremenski dogodki (v nadaljevanju: IVD), kot so močen veter, močen dež ali sneg, žled, toča itd. ali različne kombinacije teh dogodkov, lahko povzročijo škodo na hidroin termoelektrarnah, jedrskih in vetrnih elektrarnah, sončnih panelih, daljnovodih in transformatorskih postajah (Auld idr., 2006; McColl idr., 2012; Schaeffer idr., 2012; Mednarodna agencija za jedrsko energijo, ang. International Atomic Energy Agency, v nadaljevanju: IAEA, 2013; Patt idr., 2013, in Sieber, 2013). Medvladni forum za podnebne spremembe (ang. Intergovernmental Panel on Climate Change, v nadaljevanju: IPCC, 2012, 2013) ugotavlja, da se je intenzivnost IVD v zadnjem obdobju povečala, hkrati pa se je povečala tudi pogostnost IVD podobnih intenzivnosti (krajšanje povratnih dob), kar je mogoče pričakovati tudi v prihodnosti. Energetska infrastruktura ima dolgo življenjsko dobo, zato bodo imele odločitve o njenih lokacijah in izvedbi, ki jih sprejemamo v sedanjosti, dolgoročne posledice. $\mathrm{V}$ postopku načrtovanja bo zato treba upoštevati tudi postopne spremembe podnebja in IVD. $\mathrm{V}$ ta namen je treba preučiti mogoče varstvene in prilagoditvene ukrepe (Auld idr., 2006; Wilbanks idr., 2008; Rübbelke in Vögele, 2011; Schaeffer idr., 2012, in IAEA, 2013). Gradnja energetske infrastrukture, ki bo odporna proti postopnim podnebnim spremembam in IVD, je eden ključnih ukrepov prilagajanja energetskega sektorja podnebnim spremembam (Auld idr., 2006; Cortekar in Groth, 2015, ter Panteli in Mancarella, 2015), kar se poudarja tudi v mednarodnih in nacionalnih dokumentih - na primer Okvirna konvencija Združenih narodov o podnebnih spremembah (ang. United Nations Framework Convention on Climate Change, 2014), Strategija EU za prilagajanje podnebnim spremembam (Evropska komisija, 2013) in ameriški osnutek načrta prilagajanja podnebnim spremembam (ang. Climate change adaptation plan: Public review draft; ameriška agencija za varstvo okolja, ang. United States Environmental Protection Agency, v nadaljevanju: EPA, 2012a). V Sloveniji je bila v osnutku predloga nacionalnega energetskega programa (glej Institut Jožef Stefan, 2011) v ciljih za zanesljivost oskrbe navedena $\gg$ zanesljivost energetskih storitev v izrednih razmerah, kot so naravne katastrofe «. Osnutek predloga nacionalnega energetskega programa iz leta $2011 \mathrm{ni}$ bil sprejet niti se ni začel izvajati. Proces odločanja je po javni obravnavi in čezmejni presoji zamrl, tako da je dokument ostal na ravni osnutka predloga. Splošni programski dokument na področju energetike je še vedno Resolucija o Nacionalnem energetskem programu iz leta 2004 (Ur. l. RS, št. 57/2004). Nadomestil jo bo Energetski koncept Slovenije, ki je v pripravi. Predlog usmeritev za pripravo Energetskega koncepta (Ministrstvo Republike Slovenije za infrastrukturo, 2015) med tremi temeljnimi cilji trajnostne energetike navaja zanesljivost oskrbe $\mathrm{z}$ energijo, ki bi jo dosegli $\mathrm{z}$ dobro razvitimi in zanesljivimi omrežji ter z razpršitvijo virov. Odpornost infrastrukture na IVD ni izrecno omenjena.

Obstajata dva pristopa za preprečevanje škod na energetski infrastrukturi: tehnične (mehanske) izboljšave posameznih delov, kar zagotavlja večjo robustnost oziroma odpornost na fizični stres, ter preudarno umeščanje na lokacije, na katerih je ranljivost infrastrukture zaradi postopnih podnebnih sprememb in IVD manjša (Auld idr., 2006, in IAEA, 2013). Operativno se drugi pristop naslanja na prostorsko načrtovanje. Načrtovanje rabe prostora, ki upošteva tveganja zaradi različnih dejavnikov, je stroškovno učinkovitejše kot strukturni ukrepi za zmanjševanje teh tveganj (Sudmeier-Rieux idr., 2015). Raziskave, ki se nanašajo na integriranje ocene tveganja v prostorsko načrtovanje (na primer Applied multi risk mapping of natural hazards for impact assessment, ARMONIA, Lancaster University, 2007; Sutanta idr., 2010; Storch in Downes, 2013, in Prawiranegara, 2014), se osredotočajo predvsem na oblikovanje sistema za podporo odločanju, ne pa na razvoj metod za razporeditev objektov. S člankom želimo zapolniti to vrzel in prikazati, na kakšen način je mogoče obstoječe pristope oziroma prakse načrtovanja rabe prostora dopolniti, da bodo vključevali tudi upoštevanje ocene tveganja zaradi postopnih podnebnih sprememb in IVD.

Raziskovalno ozadje in povezana hipoteza sta, da je z vključitvijo ocene tveganja $v$ prostorsko načrtovanje mogoče vplivati na zmanjšanje škod zaradi IVD na energetski infrastrukturi. V članku najprej predstavimo pomen prostorskega načrtovanja za zmanjševanje tveganj zaradi postopnih podnebnih sprememb in IVD in dosedanjo uporabo ocene tveganja v prostorskem načrtovanju. Nato ti področji povežemo tako, da oblikujemo metodo za njuno integriranje. Sledi uporaba predlagane metode na študiji primera - tveganja za elektroenergetsko infrastrukturo v Sloveniji zaradi žleda. V študiji primera uporabimo oceno tveganja zaradi žleda pri presoji predlaganih različic načrtovanega visokonapetostnega daljnovoda, nato pa poiščemo najustreznejše lokacije za umestitev vetrnih elektrarn ob upoštevanju ocene tveganja. Sledi analiza stroškov in koristi za vetrne elektrarne, pri kateri primerjamo tri razvojne možnosti - tisto, ki tveganja zaradi žleda upošteva tako, da na območjih z največjimi tveganji ni vetrnih elektrarn; tisto, ki na območjih največjih tveganj vključuje tehnične ukrepe za preprečevanje/zmanjševanje morebitnih škod, in tisto, ki 
tveganj ne upošteva. Predstavitvi rezultatov sledi razprava o uporabnosti predlaganega pristopa ter njegovih prednostih in šibkih straneh, v sklepu pa so navedene smernice za nadaljnje raziskave.

\section{Teoretično ozadje}

\subsection{Vloga prostorskega načrtovanja pri prilagajanju na postopne podnebne spremembe in izredne vremenske dogodke}

Prostorsko načrtovanje je bilo kot osnova za prilagajanje na podnebne spremembe prepoznano $\mathrm{v}$ znanstveni literaturi (Biesbroek idr., 2009; Wilson in Piper, 2010, ter Hurlimann in March, 2012; Rastandeh, 2015) in več strateških dokumentih, kot so Zelena in Bela knjiga Evropske komisije (Evropska komisija, 2007, 2009) in Teritorialna agenda Evropske unije (Evropska komisija, 2011). Tudi na ravni Slovenije se prostorsko načrtovanje obravnava kot prioriteta pri prilagajanju, saj je pomemben preventivni instrument za prilagajanje podnebnim spremembam prek procesov integralnega načrtovanja in urbanega razvoja (Služba Vlade Republike Slovenije za podnebne spremembe, 2011, ter Kajfež-Bogataj idr., 2012). $\mathrm{V}$ zvezi z učinkovitostjo prostorskega načrtovanja pri prilagajanju na podnebne spremembe je bilo več študij izvedenih na mednarodni ravni (na primer International Commission for the Protection of the Alps, 2010; Pütz idr., 2011, in Linkaits, 2013), kot tudi na nacionalni (na primer Rivera in Wamsler, 2014; Flannery idr., 2015, ter Kumar in Geneletti, 2015), regionalni (na primer Rannow idr., 2010, ter De Bruin idr., 2013) in lokalni (na primer Wilson, 2006; Andersson-Sköld idr., 2015, ter Dubois idr., 2015). V Sloveniji so orodja prostorskega načrtovanja kot ukrepe prilagajanja na podnebne spremembe analizirali Mojca Golobič idr. (2012). Avtorji omenjenih študij navajajo, da je prostorsko načrtovanje dejavnost, ki ima zmožnost, da lahko pomaga družbi in gospodarstvu pri prilagoditvi na spremembe rabe tal, pri preprečevanju naravnih nesreč in integriranju različnih področij v načrtovanje (Rannow idr., 2010; Pütz idr., 2011; Greiving in Fleischhauer, 2012; Serrao-Neumann idr., 2015). Poudarjajo, da nekateri instrumenti prostorskega načrtovanja že vključujejo ukrepe prilagajanja na podnebne spremembe, vendar pa ti ne zadostujejo za prenos prilagajanja v prakso ali pa v njej niso primerno uporabljeni (Wilson, 2006; Rannow idr., 2010; Golobič idr., 2012, ter Pütz idr., 2011). Prepričani so, da se je treba od strateške ravni premakniti $\mathrm{k}$ bolj konsistentni implementaciji prilagajanja $\mathrm{s}$ pomočjo prostorskega načrtovanja na izvedbeni (praktični) ravni. Sven Rannow idr. (2010) ugotavljajo, da so ocenjevanje in upoštevanje pogostnosti in intenzivnosti izrednih dogodkov šibka točka prostorskega načrtovanja, zato bi se to pri upoštevanju IVD moralo opreti na ugotovitve drugih disciplin. Tudi zakonodaja s področja prostorskega načrtovanja obrav- nava podnebne spremembe večinoma implicitno - v okviru zaščite oziroma obnove naravnega okolja, zaščite naselij pred naravnimi nesrečami ter ekološko in gospodarsko ustreznega prostorskega razvoja (Služba Vlade Republike Slovenije za podnebne spremembe, 2011).

\subsection{Ocena tveganja in njeno vključevanje v prostorsko načrtovanje}

V zadnjih dveh desetletjih je bilo izdelanih veliko študij na temo naravnih in antropogenih tveganj ter njihovih kombinacij. Velik del teh raziskav so podprle mednarodne institucije - na primer Nato (Briggs idr., 2002), Evropska unija (raziskovalni projekti Accidental risk assessment methodology for industries - ARAMIS, 2002-2005; Sharing experience on risk management (health, safety and environment) to design future industrial systems - SHAPE-RISK, 2004-2007; ARMONIA, 2004-2007; Early recognition, monitoring and integrated management of emerging, new technology related risks - iNTeg-Risk, 2008-2013; Technology opportunities and strategies towards climate-friendly transport - TOSCA, 2010-2013; Coordination of European research on industrial safety towards smart and sustainable growth - SAFERA, 2012-2015), Urad Organizacije združenih narodov za zmanjšanje tveganja nesreč (ang. United Nations Office for Disaster Risk Reduction, v nadaljevanju: UNISDR) in Mednarodna agencija za jedrsko energijo (CRP Techno-economic evaluation of options for adapting nuclear and other energy infrastructure to long-term climate change and extreme weather, 2013-2015). Tudi znanstvena literatura, ki se nanaša na ocenjevanje tveganja, je zelo obsežna in $\mathrm{v}$ njej so obravnavana tveganja zaradi različnih izrednih dogodkov, na primer erozije (Alder idr., 2015), poplav (Camarasa-Belmonte in Soriano-García, 2012; Zhou idr., 2012; Canters idr., 2014; Prawiranegara, 2014; Foudi idr., 2015), gozdnih požarov (Thompson idr., 2015) itd. Pri tem je glavni poudarek na razvoju različnih metod za zmanjševanje posledic izrednih dogodkov. Melanie Gall idr. (2015) so preučili raziskave tveganj $\mathrm{v}$ zadnjih petnajstih letih, ki so povezovale različne znanstvene discipline, metode in udeležence. Trdijo, da je razhajanje med raziskovanjem in implementacijo v praksi zelo veliko. Čeprav je v večini omenjenih znanstvenih člankov o tveganjih poudarjeno, da razvite metode za ocenjevanje tveganja, ki jih predstavljajo, lahko služijo kot podpora pri odločanju in jih je mogoče vključiti v prostorsko načrtovanje (na primer Camarasa-Belmonte in Soriano-García, 2012; Alder idr., 2015; Foudi idr., 2015; Thompson idr., 2015), se s to integracijo $\mathrm{v}$ glavnem ne ukvarjajo podrobneje. Večina tistih študij, ki obravnavajo vključevanje ocene tveganja v prostorsko načrtovanje (Lancaster University, 2007; Sutanta idr., 2010; Storch in Downes, 2013; Prawiranegara, 2014), se osredotoča predvsem na oblikovanje sistema za podporo pri odločanju na 
podlagi kart agregiranih nevarnosti ali tveganj, ne pa na razvoj konkretnih metod za iskanje lokacij za določene dejavnosti/ rabe/objekte. Marisa Berry in Todd BenDor (2015) sta v analizo ustreznosti prostora za razvoj dejavnosti sicer vključila napovedi glede dviga morske gladine in poplavljanja zaradi neviht, vendar pa gre pri tem predvsem za umikanje dejavnosti proč od obale in nižje ležečih delov - njuna študija ne upošteva niti verjetnosti pojavljanja dogodkov niti posledic teh. Stefan Greiving idr. (2006) menijo, da ocene tveganja iz različnih znanstvenih ali strokovnih disciplin niso ustrezne za uporabo $\mathrm{v}$ prostorskem nacrrtovanju - potreben je prenos informacij o tveganjih v jezik prostorskega načrtovanja. $S$ tem sta se na primeru tveganj zaradi industrijskih nesreč ukvarjala Davor in Branko Kontić (2008). Pristop, ki ga predstavljamo v prispev$\mathrm{ku}$, nadgrajuje njuno metodo za vključevanje tveganj zaradi industrijskih nesreč v postopek prostorskega načrtovanja tako, da se osredotoča na obravnavo tveganj zaradi naravnih izrednih dogodkov. Predvidevamo, da bi z vključitvijo postopnih podnebnih sprememb in IVD v prostorsko modeliranje omogočili umeščanje energetskih objektov v prostor tako, da bi se optimizirala njihova učinkovitost in preprečila/zmanjšala morebitna škoda. V članku je prikazan pristop za izbiro ustreznih lokacij za energetsko infrastrukturo, ki smo ga razvili in testirali na primeru ocene tveganja za energetsko infrastrukturo zaradi žleda v Sloveniji.

\section{Metoda}

Metoda za vključitev rezultatov ocene tveganja v prostorsko načrtovanje temelji na pristopu, ki sta ga na primeru tveganj zaradi industrijskih nesreč razvila Davor in Branko Kontić (glej Kontić in Kontić, 2008). S pomočjo načrtovanja rabe prostora, ki upošteva verjetnost/pogostnost pojavljanja izrednih dogodkov in tudi intenzivnost/obseg posledic, sta poskušala preprečiti oziroma zmanjšati posledice industrijskih nesreč $\mathrm{v}$ bližini organizacij, ki so po Direktivi Sveta 96/82/ES z dne 9. decembra 1996 o obvladovanju nevarnosti večjih nesreč, v katere so vključene nevarne snovi (Direktiva SEVESO II; Ur. I. Evropske unije, št. 10/1997), uvrščcne v kategorijo večjega tveganja za okolje. Ta pristop smo nadgradili za obravnavo tveganj zaradi izrednih dogodkov, ki so posledica naravnih procesov, $s$ poudarkom na tveganju zaradi IVD. Izrazi, uporabljeni v prispevku, imajo v različnih kontekstih/strokah različen pomen. Izrazi tveganje, nevarnost in ranljivost imajo v okviru ocenjevanja tveganj te pomene:

- tveganje (ang. risk) - pogostnost pojavljanja (izražena s pogostnostjo ali verjetnostjo) določenih posledic kot rezultat izpostavljenosti stresorju (nevarnosti; EPA, 2012b; UNISDR, 2014);

- nevarnost (ang. hazard) - pojav, snov ali dejavnost, ki lahko povzroči negativne posledice (izguba življenja, poškodba ali drugi vplivi na zdravje, škoda na objektih, izguba storitev, ki omogočajo preživljanje, družbena in gospodarska motnja, škoda v okolju) v sistemu, ki je tej nevarnosti izpostavljen (UNISDR, 2014);

- ranljivost sistema (ang. vulnerability) - značilnosti sistema ali okolišcine, zaradi katerih je ta sistem v primeru izpostavljenosti nevarnosti dovzeten za škodo (posledice; Cardona, 2003, in UNISDR, 2014); ugotavljanje ranljivosti je namenjeno zmanjševanju tveganja z uvajanjem tehničnih ukrepov ali prilagajanju obstoječih rab.

Medvladni forum za podnebne spremembe (IPCC, 2007) pojmuje ranljivost za podnebne spremembe nekoliko drugače. Ta naj bi bila odvisna od treh dejavnikov: 1 . funkcije značaja, velikosti in obsega sprememb, ki jim je sistem izpostavljen (izpostavljenosti), 2. občutljivosti sistema in 3. njegove sposobnosti prilagajanja. Vsak od teh dejavnikov je ocenjen na osnovi meril in kazalnikov, ki so lahko opisani s pomočjo kvalitativnih ali kvantitativnih podatkov. Ranljivost okolja/prostora je izraz iz prostorskega načrtovanja in se uporablja za vnaprejšnjo identifikacijo potencialno negativnih okoljskih vplivov predvidenih dejavnosti. $V$ članku se uporabljata termina ranljivost sistema, kot je opredeljena v ocenjevanju tveganj, in ranljivost okolja/ prostora po definiciji iz prostorskega načrtovanja.

\subsection{Metoda za ocenjevanje tveganj za energetsko infrastrukturo zaradi izrednih vremenskih dogodkov}

Metodo za ocenjevanje tveganja za energetsko infrastrukturo zaradi IVD smo testirali na primeru tveganj zaradi žleda za energetsko infrastrukturo. Metodo sestavljajo štirje koraki:

1. Določitev prostorskega obsega in intenzivnosti IVD na podlagi podatkov o pojavljanju IVD v preteklosti Raven intenzivnosti različnih tipov IVD (na primer temperatura, dodatna obremenitev zaradi žleda, vetra, snega, poplav itd.) se prenese na karte v okolju GIS (glej sliko 1), kjer je vsaki celici pripisana ocena na lestvici od 1 (nizka obremenitev energetske infrastrukture) do 4 (visoka obremenitev energetske infrastrukture). Velikost celice je odvisna od obsega obravnavanega območja in podrobnosti obravnave. V prikazani analizi, izdelani na ravni celotne Slovenije, je imela celica velikost $100 \mathrm{~m}$. Podatki so bili pridobljeni iz arhivov o preteklih IVD. Pri kartiranju lokacij IVD smo se oprli na lokacijske podatke o poškodovanih daljnovodih in podatke o pasovih nadmorskih višin, $\mathrm{v}$ katerih je nastala škoda. Pri razvrščanju dogodkov v razrede glede na intenzivnost je bila upoštevana finančna škoda, ki jo je povzročil posamezni dogodek. Pragove teh razredov smo določili na podlagi sredstev, ki jih prenosno podjetje in distribucijska podjetja namenjajo za vzdrževanje infrastrukture. 


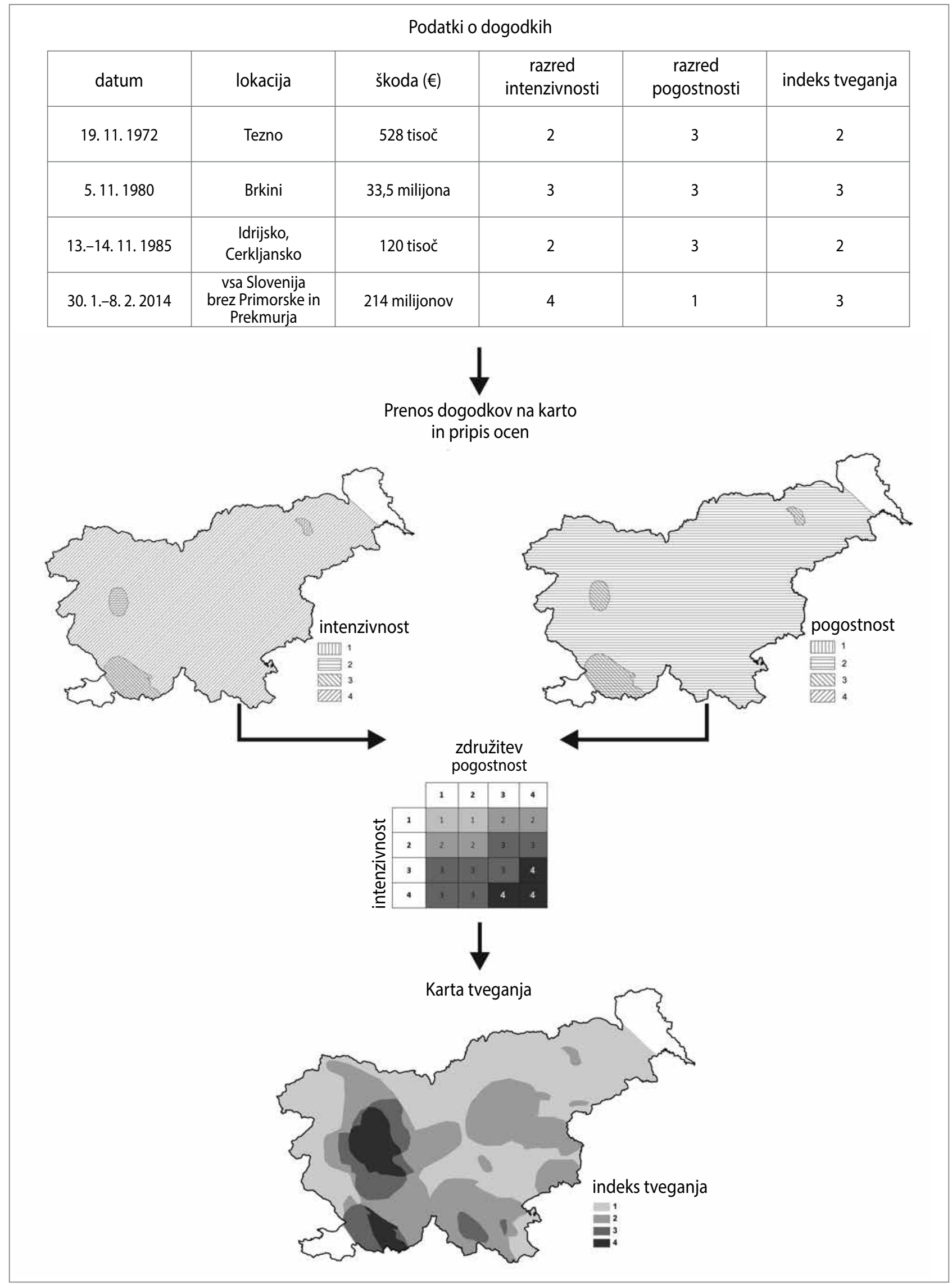

Slika 1: Postopek ocene tveganja (ilustracija: Maruša Matko) 
2. Ocena ranljivosti energetske infrastrukture oziroma območja, na katerem je infrastruktura, na določen tip IVD Namen tega koraka je ugotavljanje, ali je energetska infrastruktura na izbranem območju zmožna prenesti določeno intenzivnost IVD. IVD lahko neposredno poškodujejo energetsko infrastrukturo, poleg tega pa lahko isti IVD pripomore $\mathrm{k}$ temu, da se tudi $\mathrm{v}$ okolici pojavijo škode, ki še dodatno prispevajo $k$ poškodbam infrastrukture (na primer lomljenje dreves, erozija). Oboje je vzrok za skupno ranljivost. Ranljivost oziroma odpornost infrastrukture je mogoče neposredno ugotavljati iz statičnih oziroma mehanskih značilnosti objektov (ob upoštevanju inženirskih standardov), ranljivost okolja pa je kompleksnejša in jo je težje opredeliti, saj nanjo vpliva več dejavnikov. $\mathrm{V}$ primeru žleda smo se oprli na podatke o poškodovani lesni biomasi v gozdovih zaradi posameznih dogodkov. Ranljivost je izražena kot razmerje med pričakovano stopnjo škode in maksimalno mogočo škodo na lestvici od 1 do 4 . Rezultati so predstavljeni na karti GIS (slika 1).

3. Določitev verjetnosti/pogostnosti pojavljanja IVD na določenem območju, na katerem je energetska infrastruktura ali pa bo tja umeščena $\mathrm{v}$ prihodnosti

Na podlagi arhivskih podatkov o IVD je izračunana pogostnost ali verjetnost pojavljanja različnih tipov IVD. Rezultati so preneseni na karto.

4. Združitev zgoraj navedenih korakov za določitev fizičnih in drugih (gospodarskih, zdravstvenih) posledic ter določitve indeksa tveganja za določeno območje in energetsko infrastrukturo

Indeks tveganja združuje intenzivnost IVD in ranljivost izbrane energetske infrastrukture na določeno stopnjo intenzivnosti IVD, pogostnost ali verjetnost pojavljanja IVD in posledice - družbena škoda zaradi poškodovane infrastrukture. Te kombinacije so podobne standardnim matrikam tveganja, ki se uporabljajo za združevanje pogostnosti/ verjetnosti dogodkov s posledicami teh dogodkov.

Praktična izvedba ocene tveganja za izbrane štiri žledne dogodke in povzročeno škodo je ponazorjena na sliki 1. Najprej so bili zbrani podatki o pojavih žleda, njihovih lokacijah in škodah, ki so jih povzročili. Vsak dogodek je bil nato narisan na karto v okolju GIS (glej sliko 1) in na podlagi nastale škode (ki je odvisna od intenzivnosti dogodka in od ranljivosti sistema) uvrščen v razred intenzivnosti. Poleg tega je bil vsak dogodek uvrščen tudi v razred pogostnosti pojavljanja. Na sliki 1 je za prikaz intenzivnosti in pogostnosti izbranih dogodkov zaradi večje nazornosti prikaza uporabljena šrafura, zaradi katere je razvidno, kako se dogodki v prostoru sledijo drug drugemu, kar vpliva na končni rezultat. Zaradi večje berljivosti so na kartah intenzivnosti in pogostnosti prikazani le izbrani štirje dogodki, za podatke o vseh dogodkih glej članek Maruše Matko idr. (2015). Z združitvijo razredov intenzivnosti in pogostnosti je bil vsakemu dogodku pripisan indeks tveganja, nato pa so bili indeksi tveganj vseh dogodkov združeni v končni rezultat - karto tveganja. Karta tveganja na sliki 1 združuje vse obravnavane žledne dogodke.

Ocena tveganja za prenosno in distribucijsko omrežje zaradi žleda temelji na podatkih o preteklih škodah na elektroenergetski infrastrukturi in škodah v gozdovih. Na podlagi arhivskih podatkov o žledenju Agencije Republike Slovenije za okolje med letoma 1961 in 2014 in poročil o nastalih škodah zaradi žleda (Šifrer, 1977; Radinja, 1983; Kern in Zadnik, 1987; Papler, 1996; Bogataj, 1997; Jakša, 1997; Jakše, 1997; Kastelec, 1997; Lapajne, 1997; Nadižar in Papler, 1997; Šipec,1997; Trontelj, 1997a; Trontelj, 1997b; Zadnik, 1997; Špehar, 1998; Rebula, 2001; Rebula, 2002; Zadnik, 2006; Habjan in Bahun, 2009; Habjan, 2010; Sinjur idr., 2010; Bahun, 2014; Bahun idr., 2014; Belak in Maruša, 2014; Belak idr., 2014; Jakomin, 2014; Zavod za gozdove Slovenije, 2014, in Elektro Slovenija, 2015) so bili zbrani podatki o osnovnih značilnostih posameznega dogodka (območje, na katerem je prišlo do dogodka, škoda v gozdovih - po površini in poškodovani lesni biomasi) ter škodah na prenosnem in distribucijskem omrežju (dolžina poškodovanih daljnovodov in število poškodovanih stebrov ter $s$ tem finančna škoda, število odjemalcev brez električne energije). Finančna škoda na elektroenergetski infrastrukturi je bila iz podatkov o fizični škodi preračunana na podlagi šifranta $\mathrm{F}$ - povprečna cena po skupinah del v elektroenergetskem omrežju (Uprava Republike Slovenije za zaščito in reševanje, 2014), ki je bil uporabljen pri izračunu škode zaradi žlednega dogodka v letu 2014. Za preračun finančne škode $\mathrm{v}$ gozdovih smo uporabili povprečno odkupno ceno lesa v zadnjem desetletju, ki znaša približno 50 evrov $/ \mathrm{m}^{3}$ (Statistični urad Republike Slovenije, 2015). Škoda v gozdovih in škoda $\mathrm{v}$ energetiki sta bili obravnavani ločeno - za vsako področje je bila najprej izdelana ocena tveganja in pripravljena karta, nato pa so bili rezultati združeni. Glede na povzročeno fizično škodo na elektroenergetski infrastrukturi in $\mathrm{v}$ gozdovih ter $s$ tem glede na finančno škodo so bili dogodki razvrščeni v razrede od 1 do 4 ( 1 - najmanjša škoda, 4 - največja škoda). $\mathrm{Za}$ vsak dogodek je bila izračunana pogostnost pojavljanja $\mathrm{v}$ obravnavanem obdobju (1961-2015). Tudi po pogostnosti so bili dogodki razvrščeni v razrede od 1 (zelo redko) do 4 (pogosto). Intenzivnost žleda in pogostnost pojavljanja sta bili združeni z matriko. Tako je bil vsak dogodek uvrščen v razred indeksa tveganja (1 - najmanjše tveganje, 4 - največje tveganje). Dogodki, razvrščeni glede na indeks tveganja, so bili narisani na karti - končni rezultat je bila karta tveganja, ki jo prikazuje slika 2. 


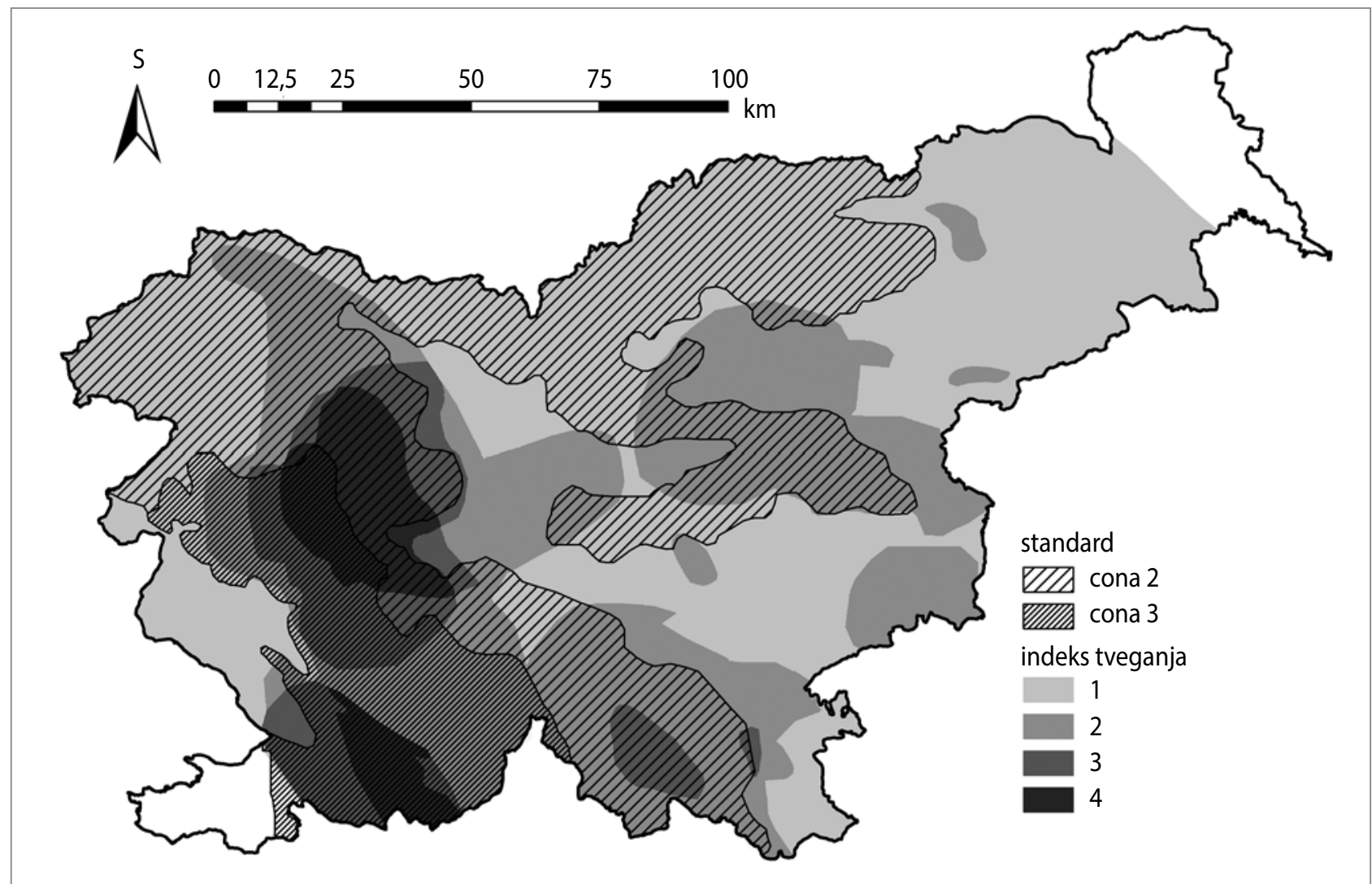

Slika 2: Karta tveganja za elektroenergetsko infrastrukturo zaradi žleda, prekrita s standardom SIST EN 50341-3-21 za gradnjo visokonapetostnih nadzemnih vodov (ilustracija: Maruša Matko).

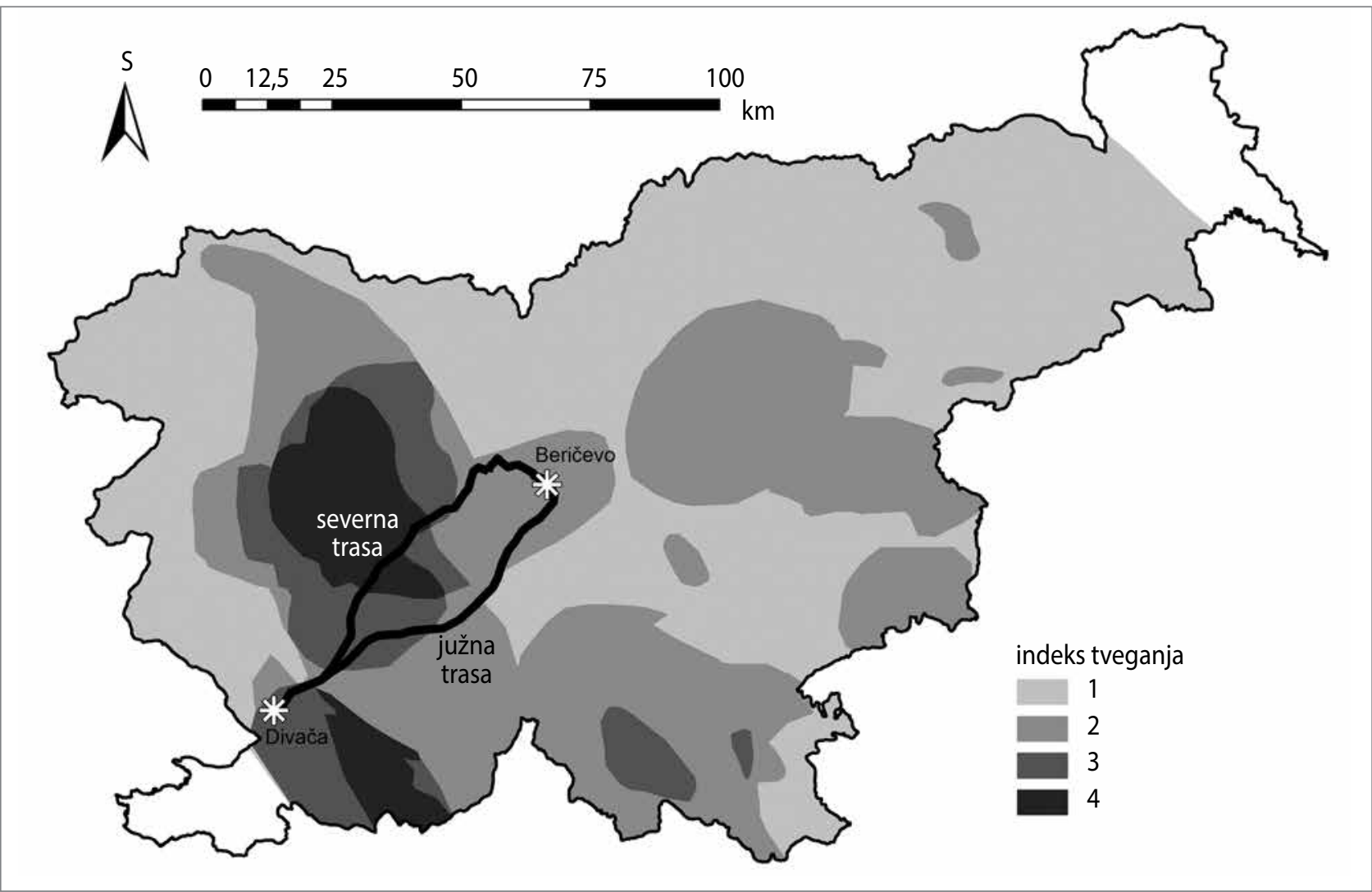

Slika 3: Karta tveganja za elektroenergetsko infrastrukturo zaradi žleda in predlagani različici tras daljnovoda 400 kV Beričevo-Divača (ilustracija: Maruša Matko) 


\subsection{Metoda vključevanja rezultatov ocene tveganja $v$ analizo ustreznosti prostora za določeno dejavnost}

Za območje Slovenije je bila najprej izdelana analiza ustreznosti prostora za umestitev vetrnih elektrarn. V Sloveniji je analiza ustreznosti prostora za določeno dejavnost $\mathrm{v}$ prostorskem načrtovanju uveljavljena od začetka devetdesetih let dvajsetega stoletja. Sestoji iz dveh delov: analize privlačnosti prostora za obravnavano dejavnost in analize ranljivosti okolja zaradi te dejavnosti. Analiza privlačnosti prostora za dejavnost ocenjuje značilnosti prostora $\mathrm{v}$ kontekstu tehnične in gospodarske izvedljivosti oziroma privlačnosti za izvedbo načrtovanega razvojnega projekta. Analiza ranljivosti okolja hkrati ugotavlja, kako ranljivo je isto območje zaradi te dejavnosti, in služi kot orodje za zgodnje opozarjanje na vplive, ki jih bo dani razvojni projekt imel na okolje, če bo izveden. Rezultati analize privlačnosti in analize ranljivosti so $\mathrm{z}$ optimizacijo združeni v model ustreznosti. Celoten postopek je izveden v okolju GIS. Metoda in postopek analize ustreznosti v članku nista podrobno opisana, ker sta sledila standardnim pristopom (Marušič, 1993; Marušič idr., 1993; Koblar idr., 1997; Marušič idr., 2004). Merila, upoštevana pri analizi privlačnosti prostora za vetrne elektrarne, so: vetrne razmere (povprečna letna hitrost vetra po modelih AIOLOS in Aladin - DADA; najprivlačnejša so območja, na katerih je hitrost vetra $5 \mathrm{~m} / \mathrm{s}$ ali več), površinski pokrov kot dejavnik hrapavosti terena, bližina visokonapetostnega elektroenergetskega omrežja (daljnovodov in transformatorskih postaj), dostopnost - bližina cest, naklon terena, matična podlaga, stabilnost zemljišča, možnost vodne erozije, poplavna območja. Pri modelu ranljivosti smo upoštevali poti velikih zveri, življenjski prostor medveda, podatke Društva za opazovanje in proučevanje ptic Slovenije o življenjskem prostoru ptic, ekološko pomembna območja, varovana območja Natura 2000 po Ptičji in Habitatni direktivi in zavarovana naravna območja, človekovo bivalno okolje (naselja, turistična območja, kulturna dediščina, varstvena območja vodnih virov), vidne kakovosti (izjemne krajine, območja varstva kulturne dediščine, zavarovana območja - še posebej vidno izpostavljena območja, vidna s pogosto obiskanih točk), hidrosfero in pedosfero ter potenciale za rabo in razvoj. Oceno tveganja smo vključili v analizo ustreznosti prostora kot njen tretji del; iz izhodiščnega modela ustreznosti za vetrne elektrarne smo na podlagi ocene tveganja izločili območja z največjo ustreznostjo, ki so bila na območjih večjega tveganja (indeks tveganja 3 ali 4). Za prvo različico ustreznosti (brez upoštevanja tveganj) in drugo (ob upoštevanju tveganj) smo izračunali skupno površino območij, na katera bi lahko umestili veliko elektrarno (z nazivno močjo vsaj $10 \mathrm{MW}$ ). Pri tem je bila kot vzorčni tip vetrnice za umestitev v prostor upoštevana vetrna turbina E-70 z nazivno močjo 2,3 MW nemškega proizvajalca Enercon (ka- kršna je obstoječa vetrna turbina v Dolenji vasi pri Senožečah), iskali pa smo območja, na katera bi lahko postavili najmanj pet tovrstnih vetrnih turbin. Obstoječe vetrne elektrarne zavzamejo v povprečju med 12 in 57 ha/MW (Denholm idr., 2009). Podatki o razdaljah med posameznimi turbinami, ki jih je mogoče najti v literaturi, pa znašajo od 3 do 15 premerov rotorja (Department of Environment, 2007; Christie in Bradley, 2012, ter Meyers in Meneveau, 2011). V analizah smo pri umeščanju vzorčnih vetrnih elektrarn predvidevali, da je razdalja med vetrnicami v vrsti $215 \mathrm{~m}$ (trije premeri rotorja), razdalja med vrstami pa $355 \mathrm{~m}$ (pet premerov rotorja), kar pomeni, da smo $s$ karte ustreznosti odčitali tiste površine z največjo ustreznostjo, ki so bile velike vsaj $200 \mathrm{~m} \times 1000 \mathrm{~m}$ (za postavitev petih vetrnic v vrsto) ali $500 \mathrm{~m} \times 600 \mathrm{~m}$ (za postavitev petih vetrnih turbin v gručo). Slovenska praksa sicer pri umeščanju vetrnih elektrarn predvideva manjše gostote stojišč. Tako je bila na Senožžških brdih sprva predvidena postavitev več kot 3-4 turbine na $\mathrm{km}^{2}$, vendar ker gre za precej razgiban teren, ki ima tudi druge omejitve, vetrnih turbin ni bilo mogoče razporejati s tako gostoto. Zadnji načrt za Senožeška brda predvideva različne gostote na $\mathrm{km}^{2}$, ponekod samo eno stojišce ali pa tega celo ni. Za obe različici (ustreznost brez upoštevanja tveganj in ustreznost $\mathrm{z}$ upoštevanimi tveganji) smo izračunali stroške investicije in vzdrževanja, količino proizvedene energije in za ustreznost brez upoštevanih tveganj tudi stroške zaradi fizične škode zaradi žleda. Obravnavali smo tudi tretjo možnost, pri kateri bi na območja največjih tveganj umestili vetrne elektrarne $\mathrm{z}$ vgrajenim sistemom za zaznavanje in preprečevanje nabiranja ledu na turbinah, za druga območja pa smo pri tej različici predvideli postavitev navadnih vetrnih turbin.

\subsection{Metoda primerjave stroškov in koristi}

Zaradi nabiranja žlednih oblog na vetrnih turbinah lahko pride do zaustavitve turbin ter $s$ tem do izgube proizvodnje električne energije, zmanjšanja moči zaradi spremenjene aerodinamike in hitrejše obrabe posameznih delov, nekontrolirano odpadanje večjih kosov ledu pa pomeni nevarnost za ljudi in objekte v bližini (Dalili idr., 2007, ter Grünevald idr., 2012). Zaradi posledic žlednega dogodka novembra 2013 v Teksasu, ki je povzročil veliko fizično škodo na turbinah in prenosnem omrežju, sta bili ukinjeni vetrni elektrarni s skupno nazivno močjo $78 \mathrm{MW}$. Upravljavci so izračunali, da stroški za popravilo škode presegajo vrednost oziroma koristi ponovnega zagona (Micek, 2014). Sodobne vetrne turbine lahko imajo vgrajen sistem za zaznavanje ledu in preprečevanje njegovega nabiranja (Deutsche WindGuard, 2011). Za pomoč pri odločanju glede umeščanja v prostor smo za obe različici ustreznosti za postavitev vetrnih elektrarn v Sloveniji izračunali, kako morebitne škode zaradi žleda vplivajo na količino proizvedene energije in kolikšne so finančno izražene škode morebitnih popravil. Pri tem smo analizirali tudi različico, pri kateri imajo 


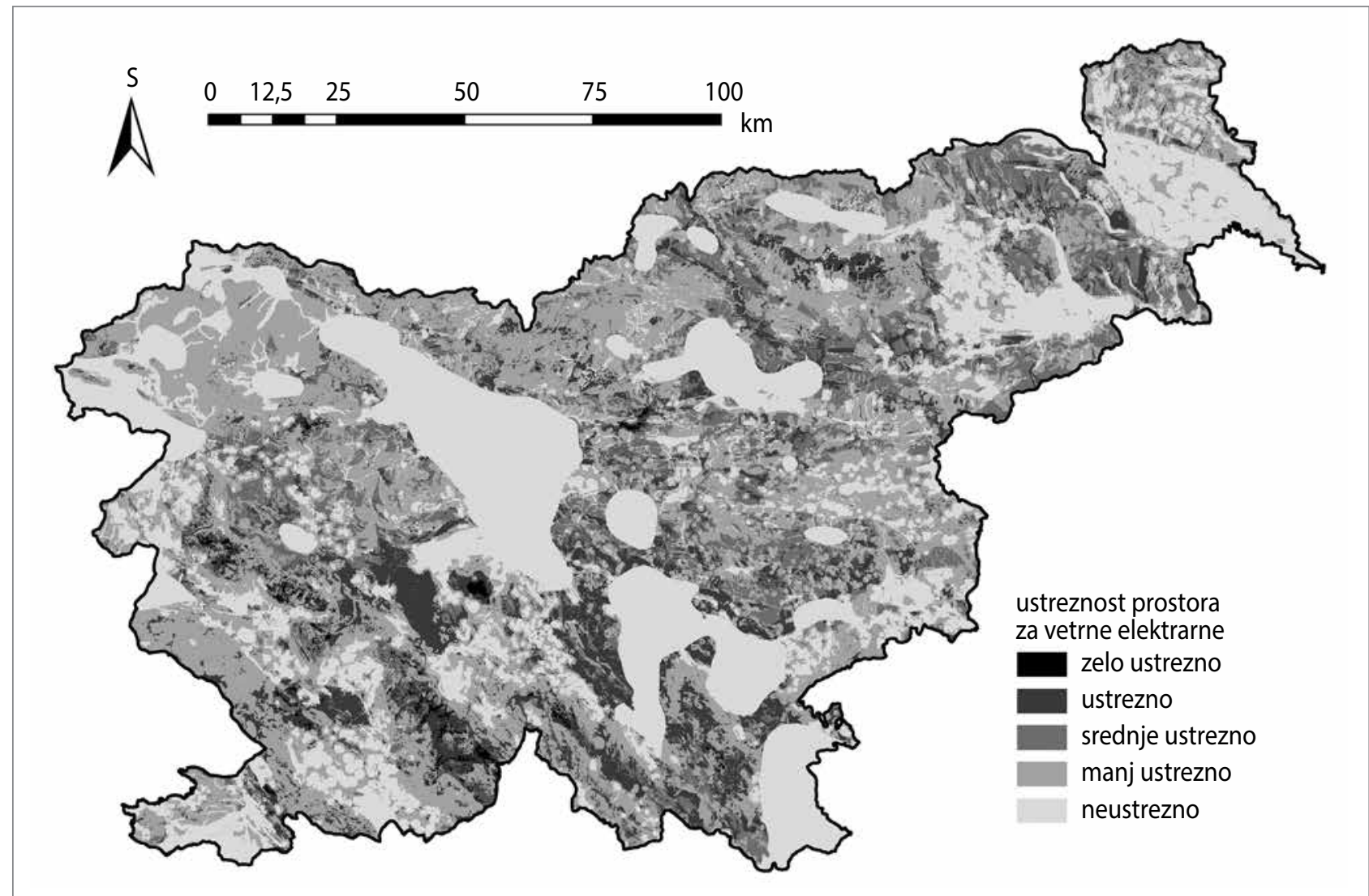

Slika 4: Ustreznost prostora za vetrne elektrarne brez upoštevanja tveganja zaradi žleda (ilustracija: Maruša Matko)

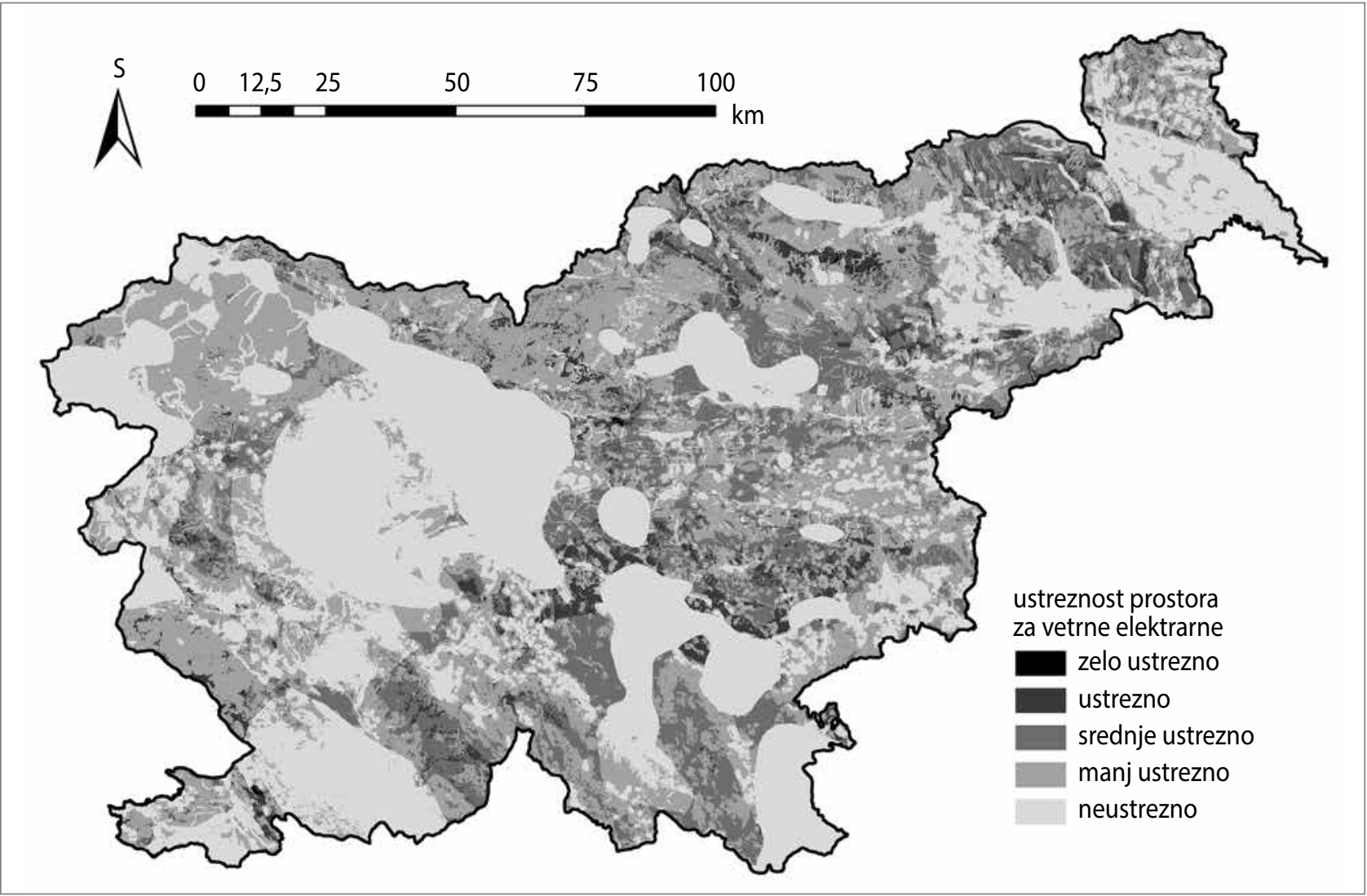

Slika 5: Ustreznost prostora za vetrne elektrarne ob upoštevanju tveganja zaradi žleda (ilustracija: Maruša Matko) 
turbine na območjih z največjim tveganjem vgrajen sistem za zaznavanje in preprečevanje nastajanja ledu. Upoštevali smo 25-50-letno obdobje (zaokroženo), saj lahko v tem času pride do dogodkov, pri katerih so lahko škode na elektroenergetski infrastrukturi velike (indeks tveganja 3, kadar lahko na prenosnem in distribucijskem sistemu nastane od 1 milijona do 10 milijonov evrov škode, pogostnost 0,037/leto, in indeks tveganja 4, kadar lahko nastane škoda, višja od 10 milijonov evrov, pogostnost $0,0185 /$ leto). Pri vseh treh različicah - prva $\mathrm{z}$ upoštevanjem žlednega dogodka, druga s tehnično izboljšavo (sistem za preprečevanje nabiranja ledu) za vetrne elektrarne na območjih z največjim tveganjem in tretja brez upoštevanja tveganja - so bili upoštevani stroški postavitve, obratovanja in vzdrževanja. Podatek o višini investicije temelji na podatkih o investiciji za obstoječo vetrno turbino v Dolenji vasi pri Senožžčah (Ministrstvo Republike Slovenije za infrastrukturo, 2013) in na izračunih nacionalnega laboratorija za obnovljivo energijo ameriškega ministrstva za energijo (ang. National Renewable Energy Laboratory of the U. S. Department of Energy; Moné idr., 2015). Ta znesek znaša približno tri milijone evrov. Sistem za detekcijo ledu in preprečevanje njegovega nabiranja na turbinah poveča investicijo za $2-6 \%$, na stroške obratovanja in vzdrževanja pa ne vpliva bistveno (Eriksson, 2013). V izračunih investicije v take vetrne elektrarne smo uporabili srednjo vrednost $-4 \%$. Porabljeno energijo za ogrevanje lopatic rotorja smo zanemarili (pulzirajoče, kratkotrajno delovanje). Tudi razpoložljivost tovrstnih vetrnih turbin je nekoliko večja od turbin brez vgrajenega sistema za zaznavanje in preprečevanje nabiranja ledu, kar v izračunih izravna porabljeno energijo za ogrevanje - odtaljevanje oblog. $V$ dostopni literaturi je razpon vrednosti stroškov vzdrževanja in obratovanja zelo velik. Tako Ryan Wiser in Mark Bolinger (2014) v analizi empiričnih podatkov o vetrnih elektrarnah v ZDA ugotavljata, da stroški obratovanja in vzdrževanja za vetrne elektrarne, postavljene po letu 2010, znašajo 23 dolarjev/kW na leto. $V$ podatkih, ki sta jih obravnavala, ni vedno jasno navedeno, kaj je vključeno $v$ te stroške, $v$ večini primerov pa gre za stroške za plače, material in rente. Po drugi strani Christopher Moné idr. (2015) trdijo, da podatek iz prej omenjene študije upošteva le variabilne stroške, ne vključuje pa zavarovanja, davkov, najemnin za zemljišča in amortizacije. Izračunali so, da ob upoštevanju teh stroškov znašajo skupni stroški vzdrževanja in obratovanja 50 dolarjev/ $\mathrm{kW}$ na leto. Med stroške nenačrtovanega vzdrževanja vključujejo tudi naključne odpovedi, vendar iz prispevka ni jasno razvidno, ali so lahko vzrok za te tudi IVD. V študiji Mednarodne agencije za energijo (ang. International Energy Agency, v nadaljevanju: IEA, 2015) so analizirali stroške vzdrževanja in obratovanja vetrnih elektrarn na Danskem, v Nemčiji, na Irskem, Norveškem, v Evropski uniji in ZDA. Leta 2012 je v Nemčiji znašal letni strošek obratovanja in vzdrževanja vetrnih elektrarn 55,9 evra/kW, na Irskem 55 evrov $/ \mathrm{kW}$ in $\mathrm{v}$ ZDA 50 dolarjev $/ \mathrm{kW}$. Za nekatere države podatki zaradi ne- zanesljivosti niso podani. $\mathrm{V}$ izračunu smo upoštevali vrednost 56 evrov/kW. Nick Middeldorf in Andreas Düing (2012) sta v svoji raziskavi predvidevala, da se zemljišča za postavitev vetrnih turbin kupijo in da je ta strošek del investicije. Med stroške vzdrževanja in obratovanja pa sta vštela pogodbo o vzdrževanju $s$ proizvajalcem turbin, zavarovanje, stroške energije in upravljanja. Po njunih ugotovitvah znašajo stroški vzdrževanja in obratovanja za turbino Enercon E-70 v prvih dveh letih obratovanja 13 tisoč evrov, v poznejšem obdobju pa 24 tisoč evrov letno. $V$ izračunu smo upoštevali vse štiri vire podatkov in jih primerjali med seboj. Podatki zadostujejo za raven podrobnosti naše obravnave, vendar pa bi bilo treba za natančnejše analize doreči, kateri stroški vzdrževanja in obratovanja se upoštevajo v Sloveniji na podlagi obstoječe elektrarne in predvidenih projektov. Cena električne energije je bila izračunana iz podatkov o tržni ceni električne energije v Sloveniji v obdobju 2009-2015 Javne agencije Republike Slovenije za energijo (Borzen, 2015) in znaša približno 50 evrov/MWh. Za velike vetrne elektrarne sicer obstajajo spodbude $s$ strani države v obliki obratovalne podpore, ki za leto 2015 znašajo 52,64 evra/MWh, vendar smo pri izračunu neto sedanje vrednosti (v nadaljevanju: NSV) zaradi negotovosti v zvezi $s$ podporami v prihodnosti upoštevali le tržno ceno električne energije. Upoštevanje subvencij pri izračunu NSV bi močno vplivalo na rezultat, saj je lahko cena električne energije s podporami tudi do dvakrat višja od tržne. Za obravnavano obdobje smo kot diskontno stopnjo upoštevali dvoodstotno letno inflacijo, kar je cilj Evropske centralne banke za evroobmočje. V primeru žlednega dogodka je treba prenoviti 190 vetrnih turbin, ki so na območjih, na katerih je tveganje zaradi žleda največje. Turbina predstavlja $68 \%$ celotne investicije (Moné idr., 2015), kar znaša skupno 388 milijonov evrov.

\section{Rezultati}

\subsection{Tveganje za elektroenergetsko infrastrukturo zaradi žleda}

Rezultat analize žlednih dogodkov na podlagi njihove intenzivnosti in pogostnosti pojavljanja je karta tveganja, prikazana na sliki 2. Na belo obarvanih območjih (v Prekmurju in na Obali) v celotnem obdobju opazovanja ni prišlo do škod zaradi žleda. Nasprotno pa se večje škode (nad 10 milijonov evrov) najpogosteje (več kot 0,2-krat letno) pojavljajo na najtemnejših območjih (Brkini, Idrijsko in Cerkljansko hribovje, okolica Logatca). Večina slovenskega ozemlja ima indeks tveganja 1 (svetlo siva barva), pri katerem so škode na elektroenergetski infrastrukturi majhne, pojavljajo pa se lahko do 0,2-krat letno. Za primerjavo je bila karta tveganja za elektroenergetsko infrastrukturo zaradi žleda prekrita s karto žlednih con po standardu SIST EN 50341-3-21 za gradnjo visokonapetostnih nadzemnih vodov (Slovenski inštitut za standardizacijo, 2009), kot prikazuje slika 2. Standard deli ozemlje Slovenije na tri 
cone, in sicer glede na obtežbo, ki jo je treba upoštevati pri projektiranju daljnovodov. V coni 1 nastajajo le majhne žledne obtežbe, ki v preteklosti niso povzročale poškodb nadzemnih vodov. V coni 2 se pričakujejo visoke žledne obtežbe, zaradi njih je na teh območjih v preteklosti že prišlo do poškodb daljnovodov. V coni 3 so območja, na katerih se na osnovi vremenskih pogojev, geografske lege in dolgoletnih izkušenj pričakujejo visoke žledne obremenitve. Tovrstne obremenitve so v preteklosti povzročile pomembne škode na nadzemnih vodih. Glede na ugotovitve ocene tveganja bi bilo smiselno posodobiti standard - razširiti cono 3 na območja, na katerih je obtežba zaradi žleda največja. Na osnovi zbranih podatkov, opravljenih analiz in izračunov ter izpeljanih sinteznih rezultatov je bila opravljena tudi primerjava predlaganih različic državnega prostorskega načrta za nadgradnjo $400 \mathrm{kV}$ daljnovoda Beričevo-Divača (slika 3), da bi se prikazala uporaba zadevne ocene tveganja za prostorsko načrtovanje - izbira ustreznejšega koridorja oziroma trase. Ob upoštevanju rezultatov, prikazanih na sliki 2, je za postavitev novega visokonapetostnega daljnovoda Beričevo-Divača primernejši južni koridor.

\subsection{Ustreznost prostora za umestitev vetrnih elektrarn}

Karta ustreznosti za postavitev vetrnih elektrarn, ki upošteva tudi tveganja zaradi žleda, je prikazana na sliki 4. V Sloveniji je približno $68 \mathrm{~km}^{2}$ ustreznih površin za postavitev vetrnih elektrarn. Med temi območji smo izbrali tista, na katera bi bilo mogoče umestiti velike vetrne elektrarne - najmanj 5 vetrnic tipa E-70 proizvajalca Enercon (elektrarna v Dolenji vasi). Površina teh območij (brez upoštevanja tveganj) znaša dobrih $31 \mathrm{~km}^{2}$. Na ta območja bi lahko postavili 405 referenčnih vetrnih turbin. Njihova skupna instalirana moč bi znašala $930 \mathrm{MW}$, skupna letna proizvodnja pa bi ob domnevi, da bi obratovale 1800 ur na leto, znašala 1,68 TWh. Ob izločitvi območij z največjim tveganjem je najustreznejših površin za umestitev najmanj petih vetrnih turbin $17 \mathrm{~km}^{2}$. Ta območja so prikazana na sliki 4 . Na ta območja bi bilo mogoče postaviti 215 vetrnic s skupno nazivno močjo 495 MW. Skupna letna proizvodnja električne energije bi znašala $890 \mathrm{GWh}$.

\subsection{Primerjava stroškov in koristi}

Podatki NSV stroškov in koristi za vse tri različice postavitve vetrnih elektrarn brez upoštevanja pojavljanja žleda in z njim - slednje zunaj območij s tveganji zaradi žleda in z upoštevanjem tehnične izboljšave za odtaljevanje - so prikazani v preglednici 1. Pri prvi različici, po kateri bi postavili vetrne elektrarne tudi na območja z največjimi tveganji (najtemnejša območja na sliki 2), so stroški glede na vse vire podatkov večji od koristi. Različica, ki upošteva tveganja zaradi žleda tako, da uvaja tehnične izboljšave (sistem ogrevanja lopatic rotorja), ima lahko pri upoštevanih nizkih stroških obratovanja in vzdrževanja (Middeldorf in Düing, 2012) pozitivno neto sedanjo vrednost (247 milijonov evrov), upoštevajoč stroške po Wiserju in Bolingerju (2014) je NSV 42 milijonov evrov, upoštevajoč stroške po Monéju idr. (2015) in IEA (2015) pa je NSV vetrnih elektrarn tudi brez žlednega dogodka negativna (-403 milijone evrov oziroma -605 milijonov evrov). Različica, ki upošteva tveganja zaradi žleda tako, da vetrnic na območjih $\mathrm{z}$ večjimi tveganji ni, ima ob upoštevanju različnih virov podatkov prav tako lahko pozitivno neto sedanjo vrednost (143 milijonov evrov, Middeldorf in Düing, 2012, ali 34 milijonov evrov, Wiser in Bolinger, 2014) ali pa negativno (-202 milijona evrov, Moné idr., 2015, ali -311 milijonov evrov, IEA, 2015). Praktičen vpliv in rezultat teh ugotovitev sta prikazana na več različicah slike 2, odvisno od stališč investitorjev in upravljavcev vetrnih elektrarn - skladno z odločitvijo o številu, tipu, opremi in lokaciji novih enot se izhodiščna slika 2 o tveganjih ustrezno dopolni, upoštevajoč rezultate ocene stroškov in koristi (NSV). Pričakovani rezultat je, da bi razliko med koristmi in stroški ustrezno prenesli na nove (dopolnjene) karte, in sicer tako, da bi nižje končne stroške prikazali kot nižjo kategorijo posledic. Te karte bi bile osnova za končno potrditev vlaganj s strani investitorjev, bile pa bi tudi osnova za potrjevanje podrobnih prostorskih načrtov. $\mathrm{V}$ tem smislu bi moral postopek prostorskega načrtovanja predvidevati ponovitve (iteracije) ocene tveganja zaradi IVD tudi na ravni izdelave podrobnih prostorskih načrtov.

\section{Razprava}

Rezultati testiranja metode za vključevanje ocene tveganja $\mathrm{v}$ prostorsko načrtovanje elektroenergetske infrastrukture, predstavljeni v prispevku, kažejo, da je ta pregledna in operativna ter da lahko služi kot podpora v postopku odločanja. Rezultati ocene tveganja pomembno prispevajo $\mathrm{k}$ optimizaciji elektroenergetske infrastrukture in jih lahko uporabimo na več načinov. Optimizacija elektroenergetske infrastrukture ob upoštevanju tveganj zaradi IVD je lahko tehnološka ali prostorska. Tehnološka optimizacija vključuje posodobitve gradbeno-inženirskih standardov ob upoštevanju ocene tveganja (slika 2 - karta tveganja za elektroenergetsko infrastrukturo zaradi žleda). Na ta način bo prihodnji infrastrukturi zagotovljena večja mehanska trdnost oziroma odpornost. Med ukrepe za tehnološko optimizacijo spada tudi postavitev vetrnih elektrarn z vgrajenim sistemom za zaznavanje ledu in preprečevanje njegovega nabiranja. Ocena tveganja lahko služi tudi kot podpora za načrtovanje investicij v posodabljanje posameznih delov na obstoječih objektih. Pri prostorski optimizaciji elektroenergetske infrastrukture lahko oceno tveganja zaradi IVD uporabimo pri presoji že predlaganega načrta oziroma 
Preglednica 1: Primerjava stroškov in koristi za postavitev vetrnih elektrarn v 25-letnem obdobju, in sicer brez upoštevanja pojavljanja žleda (različica 1) in ob upoštevanju rezultatov ocene tveganja (različici 2 in 3)

\begin{tabular}{|c|c|c|c|c|c|}
\hline različica & NSV (stroški) & & NSV (koristi) & $\begin{array}{l}\text { NSV (razlika med } \\
\text { koristmi in stroški) }\end{array}$ & $\begin{array}{l}\text { NSV (razlika med korist- } \\
\text { mi in stroški v primeru } \\
\text { žlednega dogodka) }\end{array}$ \\
\hline \multirow{5}{*}{$\begin{array}{l}1 \text { (vetrne elektrarne } \\
\text { tudi na območjih, } \\
\text { na katerih pride do } \\
\text { žlednega dogodka) }\end{array}$} & investicija: & $-1,215$ milijarde evrov & $\begin{array}{l}\text { prodana električna } \\
\text { energija: }+1,67 \\
\text { milijarde evrov }\end{array}$ & $\begin{array}{l}\text { od }-582 \text { milijonov } \\
\text { evrov do }+270 \text { milijo- } \\
\text { nov evrov }\end{array}$ & $\begin{array}{l}\text { od -118 milijonov } \\
\text { evrov do -970 milijo- } \\
\text { nov evrov }\end{array}$ \\
\hline & $\begin{array}{l}\text { stroški vzdrže- } \\
\text { vanja + obrato- } \\
\text { vanja }\end{array}$ & $\begin{array}{l}\text {-185 milijonov evrov (Middel- } \\
\text { dorf in Düing, 2012) } \\
-390 \text { milijonov evrov (Wiser } \\
\text { in Bolinger, 2014) } \\
\text {-835 milijonov } \\
\text { evrov (Moné idr., 2015) } \\
-1,037 \text { milijarde evrov (IEA, } \\
2015 \text { ) }\end{array}$ & & & \\
\hline & $\begin{array}{l}\text { stroški zaradi } \\
\text { žlednega do- } \\
\text { godka }\end{array}$ & -388 milijonov evrov & & & \\
\hline & stroški skupaj & $\begin{array}{l}\text { od 1,4 milijarde evrov do } \\
2,252 \text { milijarde evrov }\end{array}$ & & & \\
\hline & $\begin{array}{l}\text { stroški skupaj v } \\
\text { primeru žledne- } \\
\text { ga dogodka }\end{array}$ & $\begin{array}{l}\text { od } 1,788 \text { milijarde evrov do } \\
2,640 \text { milijarde evrov }\end{array}$ & & & \\
\hline \multirow{4}{*}{$\begin{array}{l}2 \text { (vetrne elektrarne } \\
\text { tudi na območjih, } \\
\text { na katerih pride do } \\
\text { žlednega dogodka, } \\
\text { vendar turbine na } \\
\text { teh območjih imajo } \\
\text { vgrajenega sistema } \\
\text { za preprečevanje } \\
\text { nastajanja žleda) }\end{array}$} & investicija: & $-1,238$ milijarde evrov & $\begin{array}{l}\text { prodana električna } \\
\text { energija: }+1,67 \\
\text { milijarde evrov }\end{array}$ & $\begin{array}{l}\text { od }-605 \text { milijonov } \\
\text { evrov do }+247 \text { milijo- } \\
\text { nov evrov }\end{array}$ & $\begin{array}{l}\text { od }-605 \text { milijonov } \\
\text { evrov do }+247 \text { milijo- } \\
\text { nov evrov }\end{array}$ \\
\hline & $\begin{array}{l}\text { stroški vzdrže- } \\
\text { vanja + obrato- } \\
\text { vanja }\end{array}$ & $\begin{array}{l}\text {-185 milijonov evrov (Middel- } \\
\text { dorf in Düing, 2012) } \\
\text {-390 milijonov evrov (Wiser } \\
\text { in Bolinger, 2014) } \\
\text {-835 milijonov } \\
\text { evrov (Moné idr., 2015) } \\
-1,037 \text { milijarde evrov (IEA, } \\
2015 \text { ) }\end{array}$ & & & \\
\hline & $\begin{array}{l}\text { stroški zaradi } \\
\text { žlednega do- } \\
\text { godka }\end{array}$ & 0 evrov & & & \\
\hline & stroški skupaj & $\begin{array}{l}\text { od 1,423 milijarde evrov do } \\
2,275 \text { milijarde evrov }\end{array}$ & & & \\
\hline \multirow{4}{*}{$\begin{array}{l}3 \text { (vetrne elektrarne } \\
\text { samo na območjih, } \\
\text { na katerih ne pride } \\
\text { do žlednega do- } \\
\text { godka) }\end{array}$} & investicija: & -645 milijonov evrov & $\begin{array}{l}\text { prodana električna } \\
\text { energija: }+886 \\
\text { milijonov evrov }\end{array}$ & $\begin{array}{l}\text { od }-311 \text { milijonov } \\
\text { evrov do }+143 \text { milijo- } \\
\text { nov evrov }\end{array}$ & $\begin{array}{l}\text { od -311 milijonov } \\
\text { evrov do }+143 \text { milijo- } \\
\text { nov evrov }\end{array}$ \\
\hline & $\begin{array}{l}\text { stroški vzdrže- } \\
\text { vanja + obrato- } \\
\text { vanja }\end{array}$ & $\begin{array}{l}\text {-98 milijonov evrov (Middel- } \\
\text { dorf in Düing, 2012) } \\
\text {-207 milijonov evrov (Wiser } \\
\text { in Bolinger, 2014) } \\
\text {-443 milijonov } \\
\text { evrov (Moné idr., 2015) } \\
\text {-552 milijonov evrov (IEA, } \\
\text { 2015) }\end{array}$ & & & \\
\hline & $\begin{array}{l}\text { stroški zaradi } \\
\text { žlednega do- } \\
\text { godka }\end{array}$ & 0 evrov & & & \\
\hline & stroški skupaj & $\begin{array}{l}\text { od } 743 \text { milijonov evrov do } \\
1,197 \text { milijarde evrov }\end{array}$ & & & \\
\hline
\end{tabular}

Viri podatkov za izračun: Middeldorf in Düing (2012); Wiser in Bolinger (2014); Moné idr. (2015); IEA (2015) 
njegovih različic (primer analize predlaganih tras daljnovoda, slika 3), lahko pa jo vključimo v oblikovanje načrta, pri čemer iščemo lokacije, na katerih bodo škode na objektih, ki jih umeščamo v prostor, manjše ali pa do njih ne bo prišlo. Ocena tveganja je $\mathrm{v}$ analizo ustreznosti $\mathrm{v}$ izvedbenem smislu vključena kot njena tretja sestavina, sicer pa gre konceptualno za sestavino (ne)privlačnosti. Metoda za vključevanje ocene tveganja $\mathrm{v}$ prostorsko načrtovanje elektroenergetske infrastrukture je bila razvita $\mathrm{v}$ sodelovanju s predstavniki slovenskih podjetij za proizvodnjo, prenos in distribucijo električne energije. Pristop, ki smo jim ga predstavili, so ocenili kot obetaven, zdaj pa tehtajo možnosti za uporabo metode za svoje potrebe. Nadaljnje preverjanje uporabnosti opisane metode bi moralo vključevati tudi prostorske načrtovalce in povezane odločevalce. Vsekakor lahko prikazani rezultati služijo kot spodbuda za javno razpravo o potrebah po elektriki v prihodnosti, njenem zagotavljanju, o energetski mešanici in upoštevanju različnih tveganj pri umeščanju te infrastrukture $\mathrm{v}$ prostor.

Rezultat ocene tveganja - karta tveganja za slovensko elektroenergetsko infrastrukturo zaradi žleda - je pokazal, katerim območjem se je pri iskanju lokacij za novo elektroenergetsko infrastrukturo smiselno izogibati, če želimo preprečiti večje škode, in kje je za obstoječo infrastrukturo smiselno izvesti ukrepe za preprečevanje ali zmanjšanje škode. V zadnjih letih so bile posodobljene ali na novo izdelane karte tveganja zaradi žleda tudi za Francijo (Dalle in Admirat, 2011), Italijo (Bonelli idr., 2011), Švico (Grünevald idr, 2012), Kanado (Lamraoui idr., 2013) in Veliko Britanijo (Nygaard idr., 2014). Te karte temeljijo na meteoroloških modelih in/ali na podatkih meteoroloških postaj in prikazujejo območja glede na pričakovano debelino žledne obloge ali njeno trajanje. Bjørn Nygaard idr. (2014) predlagajo uporabo kart pri oblikovanju novih inženirskih standardov, Bernard Dalle in Pierre Admirat (2011) ter Paolo Bonelli idr. (2011) pa pri inženirskem projektiranju daljnovodov, ki so na določenih območjih že predvideni, in pri oblikovanju tehničnih ukrepov za preprečevanje nabiranja žleda ali njegovega odstranjevanja, ne omenjajo pa iskanja lokacij za novo infrastrukturo na podlagi svojih ocen tveganj. Dalle in Admirat (2011) omenjata uporabo karte tveganja tudi pri organizaciji nujnih popravil v primeru pojava dogodkov. Fayçal Lamraoui idr. (2013) trdijo, da lahko karta tveganja služi kot podpora pri odločanju o izvedbi določenih projektov, vendar se z uporabo ocen tveganja v odločevalskih postopkih ne ukvarjajo natančneje. Thomas Günevald idr. (2012) predlagajo uporabo karte tveganja zaradi žleda pri načrtovanju vetrnih elektrarn v kombinaciji s kartami vetrnega potenciala, vendar zamisli ne razvijejo podrobneje. Ker se omenjene raziskave ukvarjajo predvsem $s$ tehnološko optimizacijo in ne z iskanjem lokacij za novo elektroenergetsko infrastrukturo na podlagi ocen tveganj, $\mathrm{v}$ nadaljevanju primerjava naših rezultatov z drugimi ni mogoča, zato se bomo osredotočili na prednosti in slabosti metode, s katerimi smo se soočili pri testnem primeru.

Ena od težav, ki so se pokazale pri testiranju metode, je dostopnost podatkov. Beleženje podatkov o IVD in škodah, ki jih povzročajo, ni standardizirano. Podatki podjetij za prenos in distribucijo so zelo heterogeni (lahko beležijo število odjemalcev brez energije, trajanje prekinitev dobave, količino nedobavljene energije, fizično ali finančno škodo), zato jih je treba pred izvedbo ocene tveganja prilagoditi, da so primerljivi. $\mathrm{V}$ prikazanem primeru so bili v ustreznem obsegu dostopni samo podatki za direktno (fizično) škodo, zato rezultati kažejo kategorije tveganja za prenosno podjetje in distribucijska podjetja. Če bi bili na voljo tudi podatki o nedobavljeni energiji, bi bilo mogoče ob finančni škodi za prenos in distribucijo omrežja izračunati tudi finančno škodo za odjemalce in posredno gospodarsko škodo. Beleženje podatkov o škodah bi bilo smiselno poenotiti. Tudi po dolžini časovne vrste se razlikujejo od podjetja do podjetja; težko dostopni so predvsem podatki iz časa pred elektronskimi arhivi. To lahko prispeva $\mathrm{k}$ manjši natančnosti ocene tveganja, predvsem če se manjkajoči podatki o določenem IVD nanašajo na podjetje, ki deluje na območju, na katerem se ta IVD pojavlja pogosto in povzroča večje škode. Poleg tega lahko tudi škode v okolju (na primer podiranje dreves zaradi žleda) povzročijo še dodatne škode na infrastrukturi. To smo v oceno tveganja zajeli z upoštevanjem škod v gozdovih. Tudi dostopni podatki o stroških za vetrne elektrarne so zelo heterogeni in lahko odločilno vplivajo na to, kakšna je neto sedanja vrednost predlaganega projekta, kot je prikazano v preglednici 1. Obravnavani viri med stroške obratovanja in vzdrževanja namreč zajemajo različne stroške (nekateri na primer predvidevajo najem zemljišč, drugi pa domnevajo, da bo zemljišč kupljeno in bo njegova cena del investicije). Prihaja tudi do razlik med podatki iz različnih držav, ki so bile obravnavane v navedenih študijah. Pred dejanskim odločanjem za umestitev objekta v prostor bi bilo zato treba v Sloveniji sprožiti diskusijo, kateri podatki naj se uporabijo $\mathrm{v}$ analizi stroškov in koristi. Dodatne negotovosti se nanašajo na prihodnje spodbude $s$ strani države za uporabo obnovljivih virov energije, zato je bila pri izračunih koristi zaradi prodane električne energije upoštevana tržna cena elektrike v Sloveniji in ne subvencionirana, ki je lahko tudi dvakrat višja. Naša ugotovitev, da v primeru žlednega dogodka stroški prerastejo koristi, je konsistentna s primerom iz prakse, $\mathrm{v}$ katerem so raje ustavili obratovanje poškodovanih vetrnih elektrarn, kot da bi jih obnovili (Micek, 2014).

\section{Sklep}

V članku smo želeli oblikovati, testirati in predstaviti metodo, ki bo povezala oceno tveganja s pristopi iz prostorskega načrtovanja. Izkazalo se je, da je prikazani pristop uporaben tako 
v prostorskem načrtovanju kot pri odločanju glede ukrepov za povečanje mehanske odpornosti, med katere spadajo tudi odločitve o vzdrževanju in posodabljanju elektroenergetske infrastrukture. Hipoteza, da lahko z vključitvijo ocene tveganja $\mathrm{v}$ prostorsko načrtovanje vplivamo na zmanjšanje škod zaradi IVD na energetski infrastrukturi, se je potrdila. Metoda je bila prikazana na primeru tveganj zaradi žleda v Sloveniji in umeščanju vetrnih turbin, uporabiti pa jo je mogoče tudi za druge IVD in različne kombinacije teh dogodkov ter v drugih regijah. Poleg tega njena uporaba ni omejena le na energetsko infrastrukturo, temveč je mogoče na ta način ocenjevati tveganja tudi za drugo kritično infrastrukturo in druge okoljske sestavine - naravne (na primer gozd, tla, vodotoki itd.) in antropogene (na primer naselja, kulturna dediščina itd.). Poleg tega je pri ocenjevanju tveganj mogoče prilagajati merilo - velikost obravnavanega območja in podrobnost analize. $\mathrm{V}$ nadaljnje raziskovanje bo treba vključiti vse omenjene vidike in izdelati ocene tveganja tudi za druge IVD, ki povzročajo škodo na elektroenergetski infrastrukturi (močen veter, težek in obilen sneg, toča, močna neurja, zaradi katerih pride do poplav in povečane erozije), za kombinacije teh dogodkov in drugo elektroenergetsko infrastrukturo (fotovoltaični paneli, hidroelektrarne, jedrske elektrarne). Naslednji korak v raziskovanju bi morala biti uporaba ocene tveganja pri oblikovanju vzdrževalnih oziroma posodobitvenih ukrepov za obstoječo infrastrukturo in pri analizi stroškovne učinkovitosti teh ukrepov.

Odpira se vprašanje, kako obravnavati dogodke, $s$ katerimi še nimamo izkušenj. Smiselno bi bilo uporabiti podnebne modele, ki napovedujejo spremembe pogostnosti in intenzivnosti IVD, vendar pa je ločljivost teh modelov groba, poleg tega pa pri modeliranju postopnih podnebnih sprememb in IVD obstajajo številne negotovosti glede prihodnjih izpustov toplogrednih plinov, glede oblikovanja podnebnih modelov, zmanjševanja njihovega merila z globalne ravni na regionalno ali lokalno, kot tudi glede nelinearnih razmerij med povprečnimi vrednostmi podnebnih spremenljivk in izrednimi vremenskimi dogodki (Mearns idr., 1984; Jones, 2001; Mitchell idr., 2006; Fowler idr., 2007; Van Aalst, 2006; Chen idr., 2011; Ceglar in Kajfež-Bogataj, 2012; IPCC, 2012; Sunyer idr., 2012, ter Willems idr., 2012). Gotovost napovedi o pojavljanju IVD je močno odvisna tudi od tipov obravnavanih IVD in od obravnavanih regij (Planton idr., 2008, in IPCC, 2012). Dodaten vir negotovosti pomeni modeliranje vplivov IVD na specifične sisteme, kot so kmetijstvo, gozdarstvo, energetski sektor ipd. (Fowler idr., 2007). Pri prihodnjih napovedih vplivov podnebnih sprememb na elektroenergetsko infrastrukturo bi bilo smiselno upoštevati različne kombinacije podnebnih scenarijev ter scenarijev prihodnjega družbenega in gospodarskega razvoja, kot tudi že izdelane načrte za prihodnji razvoj energetike. Nekateri tipi elektroenergetske infrastruk- ture so relativno novi (na primer sončne elektrarne), zato je za to infrastrukturo na voljo le malo informacij o tem, kako dovzetna je za škode zaradi različnih IVD. Poleg tega imamo tudi območja, na katerih $\mathrm{v}$ preteklosti določene infrastrukture ni bilo, lahko pa bo tja umeščena v prihodnosti. K zmanjšanju negotovosti pri ocenjevanju tveganja lahko prispeva uporaba več zanesljivih podatkov z različnih lokacij in za različno infrastrukturo oziroma druge okoljske sestavine. $V$ prihodnje bi bilo zato upravljavcem elektroenergetske in druge infrastrukture smiselno predlagati standardiziran sistem beleženja podatkov o vplivih IVD na njihove objekte. Obravnava različnih tehnologij za pridobivanje električne energije zahteva previdnost pri razlagi rezultatov - indeks tveganja, izračunan na podlagi škode zaradi IVD in pogostnosti njihovega pojavljanja, je lahko za različne tehnologije enak, $v$ absolutnih številkah pa se lahko škoda zaradi neproizvedene električne energije razlikuje tudi za red velikosti (na primer primerjava med proizvodnjo v hidroelektrarni ali jedrski elektrarni v Sloveniji), drugod tudi za več. Zato je treba pri razlagi indeksov tveganja in stroškov, povezanih z njimi, jasno določiti kontekst. Kako naj bo predstavljena metoda vključena $\mathrm{v}$ formalne postopke prostorskega načrtovanja, je treba še preveriti oziroma se dogovoriti s prostorskimi načrtovalci in drugimi udeleženci v teh postopkih. Dogovor s stroko bi bil predvidoma hiter, pri upravnih organih pa je mogoče pričakovati daljša dogovarjanja glede postopka. Menimo, da bi bila vključitev predstavljene metode v obstoječe postopke mogoča že z manjšimi prilagoditvami teh postopkov glede na kontekst prostorskih načrtov, merilo in potrebe (pričakovanja).

\section{Zahvala}

Raziskava je bila izvedena s podporo Evropskega socialnega sklada, Ministrstva za izobraževanje, znanost in šport Republike Slovenije in Mednarodne agencije za jedrsko energijo (IAEA). Za sodelovanje na delavnicah in posredovanje podatkov se zahvaljujemo predstavnikom iz podjetij Dravske elektrarne Maribor, Elektro Slovenija, Elektro Celje, Elektro Gorenjska, Elektro Ljubljana, Elektro Maribor, Elektro Primorska, Hidroelektrarne na spodnji Savi, Nuklearna elektrarna Krško, Savske elektrarne Ljubljana, SODO in Soške elektrarne Nova Gorica.

Maruša Matko

Institut Jožef Stefan, Ljubljana, Slovenija

E-pošta: marusa.matko@ijs.si

\section{Mojca Golobič}

Univerza v Ljubljani, Biotehniška fakulteta, Oddelek za krajinsko arhitekturo, Ljubljana, Slovenija

E-pošta: mojca.golobic@bf.uni-lj.si

\section{Branko Kontić}

Institut Jožef Stefan, Ljubljana, Slovenija

E-pošta: branko.kontic@ijs.si 


\section{Viri in literatura}

Alder, S., Prasuhn, V., Liniger, H., Herweg, K., Hurni, H., Candinas, A., idr. (2015): A high-resolution map of direct and indirect connectivity of erosion risk areas to surface waters in Switzerland - A risk assessment tool for planning and policy-making. Land Use Policy, 48(1), str. 236-249. DOI: 10.1016/j.landusepol.2015.06.001

Andersson-Sköld, Y., Thorsson, S., Rayner, D., Lindberg, F., Janhäll, S., Jonsson, A., idr. (2015): An integrated method for assessing climate-related risks and adaptation alternatives in urban areas. Climate Risk Management, 7, str. 31-50. DOI: 10.1016/j.crm.2015.01.003

Auld, H., Maclver, D., in Klaassen, J. (2006): Adaptation options for infrastructure under changing climate conditions. V: Proceedings of Engineering Institute of Canada Climate Change Technology Conference, str. 1-11. New Jersey, Institute of Electrical and Electronics Engineers. DOI: $10.1109 /$ eicccc.2006.277248

Bahun, P. (2014): Slovenija v ledenem objemu. Črni petek za slovensko elektroenergetsko omrežje. Naš stik: glasilo delavcev Elektrogospodarstva Slovenije, 32(1), str. 2-5.

Bahun, P., Janjić, B., Habjan, V., in Jakomin, M. (2014): Žledolom povzročil za več deset milijonov evrov škode. Naš stik: glasilo delavcev Elektrogospodarstva Slovenije, 32(2), str. 2-16.

Belak, L., in Maruša, R. (2014): Žled 2014 in ukrepi za odpravljanje ledu na vodnikih prenosnih vodov. Prispevek je bil predstavljen na konferenci, z naslovom 2. slovenska konferenca o vzdrževanju elektroenergetskih objektov v distribuciji in prenosu električne energije, ki je potekala 12. novembra v Novi Gorici. Tipkopis.

Belak, L., Maruša, R., Ferlič, R., Ribič, J., in Pihler, J. (2014): Analiza žledoloma $2014 \mathrm{v}$ prenosnem omrežju Elektra Slovenija. Prispevek je bil predstavljen na posvetu z naslovom 23. mednarodno posvetovanje Komunalna energetika, ki je potekal od 13. do 15. maja v Mariboru. Tipkopis.

Berry, M., in BenDor, T. K. (2015): Integrating sea level rise into development suitability analysis. Computers, Environment and Urban Systems, 51, str. 13-24. DOI: 10.1016/j.compenvurbsys.2014.12.004

Biesbroek, G. R., Swart, R. J., in van der Knaap, W. G. M. (2009): The mitigation - adaptation dichotomy and the role of spatial planning. Habitat International, 33(3), str. 230-237. DOI: 10.1016/j.habitatint.2008.10.001

Bogataj, F. (1997): Katastrofalne posledice žledu. Logaške novice, 28(1), str. 2.

Bonelli, P., Lacavalla, M., Marcacci, P., Mariani, G., in Stella, G. (2011): Wet snow hazard for power lines: A forecast and alert system applied in Italy. Natural Hazards and Earth System Sciences, 11, str. 2419-2431. DOI: 10.5194/nhess-11-2419-2011

Borzen (2015): Določanje višine podpor električni energiji proizvedeni iz OVE in SPTE in višine podpor v letu 2015. Dostopno na: https://www. borzen.si (sneto 4. 8. 2015).

Briggs, J., Forer, P., Järup, L., in Stern, R. (ur.) (2002): GIS for emergency preparedness and health risk reduction. Dordrecht, Kluwer Academic Publishers. DOI: 10.1007/978-94-010-0616-3

Camarasa-Belmonte, A. M., in Soriano-García, J. (2012): Flood risk assessment and mapping in peri-urban Mediterranean environments using hydrogeomorphology. Application to ephemeral streams in the Valencia region (eastern Spain). Landscape and Urban Planning, 104(2), str. 189-200. DOI: 10.1016/j.landurbplan.2011.10.009

Canters, F., Vanderhaegen, S., Khan, A. Z., Engelen, G., in Uljee, I. (2014): Land-use simulation as a supporting tool for flood risk assessment and coastal safety planning: The case of the Belgian coast. Ocean \& Coastal Management, 101, str. 102-113. DOI: 10.1016/j.ocecoaman.2014.07.018
Cardona, O. D. (2003): The need for rethinking the concepts of vulnerability and risk from a holistic perspective: A neccessary review and criticism for effective risk management. V: Bankoff, G., Frerks, G., in Hilhorst, D. (ur.): Mapping vulnerability: Disasters, development and peolpe. London, Earthscan Publishers.

Ceglar, A., in Kajfež-Bogataj, L. (2012): Simulation of maize yield in current and changed climatic conditions: Addressing modelling uncertainties and the importance of bias correction in climate model simulations. European Journal of Agronomy, 37(1), str. 83-95. DOI: 10.1016/j. eja.2011.11.005

Chen, J., Brissette, F. P., in Leconte, R. (2011): Uncertainty of downscaling method in quantifying the impact of climate change on hydrology. Journal of Hydrology, 401(3-4), str. 190-202. DOI: 10.1016/j. jhydrol.2011.02.020

Christie, D., in Bradley, M. (2012): Optimising land use for wind farms. Energy for Sustainable Development, 16(4), str. 471-475. DOI: 10.1016/j. esd.2012.07.005

Cortekar J., in Groth, M. (2015): Adapting energy infrastructure to climate change - Is there a need for government interventions and legal obligations within the German "Energiewende"? Energy Procedia, 73, str. 12-17. DOI: 10.1016/j.egypro.2015.07.552

Dalili, N., Edrisy, A., in Carriveau, R. (2007): A review of surface engineering issues critical to wind turbine performance. Renewable and Sustainable Energy Reviews, 13(2), str. 428-438. DOI: 10.1016/j.rser.2007.11.009

Dalle, B., in Admirat, P. (2011): Wet snow accretion on overhead lines with French report of experience. Cold Regions Science and Technology, 65(1), str. 43-51. DOI: 10.1016/j.coldregions.2010.04.015

De Bruin, K., Goosen, H., van lerland, E. C., in Groeneveld, R. A. (2013): Costs and benefits of adapting spatial planning to climate change: Lessons learned from a large-scale urban development project in the Netherlands. Regional Environmental Change, 13(2), str. 1009-1020. DOI: 10.1007/s10113-013-0447-1

Denholm, P., Hand, M., Jackson, M., in Ong, S. (2009): Land-use requirements of modern wind power plants in the United States. Dostopno na: http://www.nrel.gov (sneto 23. 10. 2015).

Department of the Environment (2007): Osnutek politike razvoja obnovljive energije. Dostopno na: http://www.planningni.gov.uk (sneto 28. 10. 2015).

Deutsche WindGuard (2011): Summary of a technical validation of Enercon's rotor blade deicing system. Dostopno na: http://www.svevind. se (sneto 20. 10. 2015).

Direktiva Sveta 96/82/ES z dne 9. decembra 1996 o obvladovanju nevarnosti večjih nesreč, $v$ katere so vključene nevarne snovi. Uradni list Evropske unije, št. 10/1997. Bruselj.

Dubois, C., Cloutier, G., Potvin, A., Adolphe, L., in Joerin, F. (2015): Design support tools to sustain climate change adaptation at the local level: A review and reflection on their suitability. Frontiers of Architectural Research, 4(1), str. 1-11. DOI: 10.1016/j.foar.2014.12.002

Elektro Slovenija (2015): Podatki o preteklih škodah na prenosnem omrežju zaradi žleda (osebni vir, junij 2015).

Eriksson, K. (2013): Icing status review. Dostopno na: http://www.powervast.se (sneto 6. 11. 2015).

Evropska komisija (2007): Zelena knjiga: Prilagajanje podnebnim spremembam v Evropi - možnosti za ukrepanje EU. Bruselj.

Evropska komisija (2009): Bela knjiga: Prilagajanje podnebnim spremembam: evropskemu okviru za ukrepanje naproti. Bruselj.

Evropska komisija (2011): Teritorialna agenda Evropske unije 2020 Gödöllö. 
Evropska komisija (2013): Strategija Evropske unije za prilagajanje podnebnim spremembam. Bruselj.

Feeley, T. J. III., Skone, T. J., Stiegel, G. J. Jr., McNemar, A., Nemeth, M., Schimmoller, B., idr. (2008): Water: A critical resource in the thermoelectric power industry. Energy, 33(1), str. 1-11. DOI: 10.1016/j. energy.2007.08.007

Flannery, W., Lynch, K., in Cinneide, M. O. (2015): Consideration of coastal risk in the Irish spatial planning process. Land Use Policy, 43 , str. 161-169. DOI: 10.1016/j.landusepol.2014.11.001

Foudi, S., Osés-Eraso, N., in Tamayo, I. (2015): Integrated spatial flood risk assessment: The case of Zaragoza. Land Use Policy, 42, str. 278-292. DOI: 10.1016/j.landusepol.2014.08.002

Fowler, H. J., Blenkinsop, S., in Tebaldi, C. (2007): Linking climate change modelling to impacts studies: recent advances in downscaling techniques for hydrological modelling. International Journal of Climatology, 27(12), str. 1547-1578. DOI: 10.1002/joc.1556

Gall, M., Nguyen, K. H., in Cutter, S. L. (2015): Integrated research on disaster risk: Is it really integrated? International Journal of Disaster Risk Reduction, 12, str. 255-267. DOI: 10.1016/j.ijdrr.2015.01.010

Golobič, M., Praper Gulič, S., Gulič, A., in Cof, A. (2012): Prilagajanje podnebnim spremembam z orodji prostorskega načrtovanja. Raziskovalni projekt $v$ okviru ciljnega raziskovalnega programa »Konkurenčnost Slovenije 2006-2013«: končno poročilo. Ljubljana, Urbanistični inštitut Republike Slovenije.

Greiving, S., in Fleischhauer, M. (2012): National climate change adaptation strategies of european states from a spatial planning and development perspective. European Planning Studies, 20(1), str. 27-48. DOI: 1 0.1080/09654313.2011.638493

Greiving, S., Fleischhauer, M., in Wanczura, S. (2006): Management of natural hazards in Europe: the role of spatial planning in selected EU member states. Journal of Environmental Planning and Management, 49(5), str. 739-757. DOI: 10.1080/09640560600850044

Grünevald, T., Dierer, S., Cattin, R., Steiner, P., Steinkogler, W., Fundel, F., idr. (2012): Mapping frequencies of icing on structures in Switzerland. Journal of Wind Engineering and Industrial Aerodynamics, 107-108, str. 76-82. DOI: 10.1016/j.jweia.2012.03.022

Habjan, V., in Bahun, P. (2009): Ukrepi ob ujmah usmerjeni v čimprejšnjo sanacijo razmer. Naš stik: glasilo delavcev Elektrogospodarstva Slovenije, 28(2), str. 2-9.

Habjan, V. (2010): Žled podiral daljnovodne stebre: Poškodbe distribucijskega omrežja Elektra Primorska. Naš stik: glasilo delavcev Elektrogospodarstva Slovenije, 29(1), str. 30.

Hurlimann, A. C., in March, A. P. (2012): The role of spatial planning in adapting to climate change. Wiley Interdisciplinary Reviews: Climate Change, 3(5), str. 477-488. DOI: 10.1002/wcc. 183

Institut Jožef Stefan (2011): Osnutek predloga Nacionalnega energetskega programa: Dolgoročne energetske bilance Republike Slovenije za obdobje 2010 do 2030 - izhodišča. Ljubljana.

International Atomic Energy Agency (2013): Techno-economic evaluation of options for adapting nuclear and other energy infrastructure to long-term climate change and extreme weather. Prispevek je bil predstavljen na prvem delovnem sestanku $v$ okviru koordiniranega raziskovalnega programa z naslovom Techno-economic Evaluation of Options for Adapting Nuclear and Other Energy Infrastructure to Long-Term Climate Change and Extreme Weather, ki je potekal od 10. do 12. aprila na Dunaju v Avstriji. Tipkopis.

International Commission for the Protection of the Alps (2010): Spatial planning in climate change: A CIPRA background report. Schaan.
International Energy Agency (2015): IEA Wind Task 26: Wind technology, cost, and performance trends in Denmark, Germany, Ireland, Norway, the European Union, and the United States: 2007-2012. Dostopno na: https:// www.ieawind.org (sneto 6. 11. 2015).

Intergovernmental Panel on Climate Change (2007): Summary for Policymakers. V: Parry, M. L., Canziani, O. F., Palutikof, J. P., van der Linden, P. J. in Hanson, C. E. (ur.): Climate change 2007: Impacts, adaptation and vulnerability. Contribution of working group II to the fourth assessment report of the intergovernmental panel on climate change, str. 1-18. Cambridge, Cambridge University Press.

Intergovernmental Panel on Climate Change (2012): Summary for Policymakers. V: Field, C. B., Baros, V., Stocker, T. F., Qin, D., Dokken, D. J., Ebi, K. L., idr. (ur.): Managing the risks of extreme events and disasters to advance climate change adaptation: A special report of working groups I and II of the intergovernmental panel on climate change, str. 3-21. Cambridge, Cambridge University Press. DOI: 10.1017/CBO9781139177245

Intergovernmental Panel on Climate Change (2013): Summary for Policymakers. V: Stocker, T. F., Qin, G., Plattner, G.-K., Tignor, M., Allen, S. K., Boschum, J., idr. (ur.): Climate change 2013: The physical science basis. Contribution of working group I to the fifth assessment report of the intergovernmental panel on climate change, str. 1-36. Cambridge, Cambridge University Press.

Jakomin, M. (2014): Zimska ujma opozorila na ranljivost in podhranjenost omrežja. Naš stik: glasilo delavcev Elektrogospodarstva Slovenije, 32(2), str. 28-29.

Jakša, J. (1997). Posledice snegoloma in žledoloma v gozdovih leta 1996. Ujma, 11, str. 49-62.

Jakše, J. (1997): Havarije v slovenski prenosni mreži. V: Pregl, M. (ur.): Jeklene konstrukcije imajo bodočnost, str. 95-103. Ljubljana, Inštitut za metalne konstrukcije.

Jones, R. N. (2001): An environmental risk assessment / management framework for climate change impact assessments. Natural Hazards, 23(2), str. 197-230. DOI: 10.1023/A:1011148019213

Kajfež-Bogataj, L., Ceglar, A., Črepinšek, Z., in Medved-Cvikl, B. (2012): Zakonodajne rešitve na področju prilagajanja na podnebne spremembe $v$ okviru predloga Zakona o podnebnih spremembah. Ljubljana, Univerza v Ljubljani, Biotehniška fakulteta, Center za agrometeorologijo.

Kastelec, D. (1997): Pojav žleda v Sloveniji. Ljubljana, Hidrometeorološki zavod Republike Slovenije.

Kern, J., in Zadnik, B. (1987): Žledenje in elektrogospodarstvo. Ujma, 1 , str. 31-35.

Koblar, J, Marušič, J., Mejač Ž., in Jug, M. (1997): Environment vulnerability maps as an input for the national plan of Slovenia. V: Methods, Tools and Techniques of Assessing the Effects of Development / 17th annual meeting, str. 37-43. New Orleans, International Association for Impact Assessment.

Kontić, D., in Kontić, B. (2008): Introduction of threat analysis into the land-use planning process. Journal of Hazardous Materials, 163(2-3), str. 683-700.

Kopytko, N., in Perkins, J. (2011): Climate change, nuclear power, and the adaptation-mitigation dilemma. Energy Policy, 39(1), str. 318-333. DOI: 10.1016/j.enpol.2010.09.046

Kumar, P., in Geneletti, D. (2015): How are climate change concerns addressed by spatial plans? An evaluation framework, and an application to Indian cities. Land Use Policy, 42, str. 210-226. DOI: 10.1016/j. landusepol.2014.07.016

Lamraoui, F., Fortin, G., Benoit, R., Perron, J., in Masson, C. (2013): Atmospheric icing severity: Quantification and mapping. Atmospheric Research, 128, str. 57-75. DOI: 10.1016/j.atmosres.2013.03.005 
Lancaster University (2007): Assessing and mapping multiple risks for spatial planning: Approaches, methodologies and tools in Europe. Lancaster, Lancaster University, Department of Geography.

Lapajne, S. (1997): Lomi daljnovodnih stebrov. Gradbeni vestnik, 46(1-3), str. 7-8.

Linkaits, T. (2013): Vision and Strategies Around the Baltic Sea (VASAB): Spatial planning and climate change adaptation. Prispevek je bil predstavljen na konferenci z naslovom The 3rd Policy Forum Climate Change - Adaptation in the Baltic Sea Region, ki je potekala 30. maja v Tallinnu v Estoniji. Tipkopis.

Marušič, J. (1993): Conservation planning within a framework of landscape planning in Slovenia. Landscape and Urban Planning, 23(3-4), str. 233-239. DOI: 10.1016/0169-2046(93)90071-K

Marušič, J, Kontić, B., Polič, S., Anko, B., Kos, D., Polič, M., idr. (1993): Technical basis for determination of content and methodology for environmental vulnerability assessment. Ljubljana, Institut Jožef Stefan.

Marušič, J., Golobič, M., Mejač, Ž., in Jug, M. (2004): Environmental assessment of developmental vision through landscape vulnerability analyses. Landscape 21, 1, str. 37-43.

Matko, M., Golobič, M., in Kontić, B. (2015): Ocena neposredne in povezane škode na energetski infrastrukturi zaradi izrednih vremenskih dogodkov: primer žleda. Ujma, 29, str. 206-213.

McColl, L., Angelini, T., in Betts, R. (2012): Climate change risk assessment for the energy sector. UK Climate change risk assessment. London, Department for Environment, Food and Rural Affairs.

Mearns, L. O., Katz, R. W., in Schneider, S. H. (1984): Extreme high-temperature events: Changes in their probabilities with changes in mean temperature. Journal of Climate and Applied Meteorology, 23(12), str. 1601-1613. DOI: 10.1175/1520-0450(1984)023<1601:EHTECI>2.0. $\mathrm{CO} ; 2$

Meyers, J., in Meneveau, C. (2011): Optimal turbine spacing in fully developed wind farm boundary layers. Wind Energy, 15(2), str. 305-317. DOI: $10.1002 /$ we.469

Micek, K. (2014): NextEra Energy to shut two Texas wind farms in a first for ERCOT. Dostopno na: http://www.platts.com (sneto 3. 8. 2015).

Middeldorf, N., in Düing, A. (2012): Wind power Ltd. Aachen, RWTH Aachen University.

Ministrstvo Republike Slovenije za infrastrukturo (2013): Prva vetrna elektrarna v Sloveniji uradno odprta. Dostopno na: http://www.energetika-portal.si (sneto 4. 8. 2015).

Ministrstvo Republike Slovenije za infrastrukturo (2015): Predlog usmeritev za pripravo energetskega koncepta Slovenije. Dostopno na: http:// www.energetika-portal.si (sneto 18. 8. 2015).

Mitchell, J. F. B., Lowe, J., Wood, R. A., in Vellinga, M. (2006): Extreme events due to human-induced climate change. Philosophical Transactions of The Royal Society, 364(1845), str. 2117-2133.

Moné, C., Smith, A., Maples, B., in Hand., M. (2015): 2013 Cost of wind energy review. Dostopno na: http://www.nrel.gov (sneto 3. 8. 2015).

Nadižar, M., in Papler, D. (1997): Zaradi žleda brez elektrike okrog 15000 gospodinjstev. Gorenjski glas, 50(2), str. 11.

Nygaard, B. E. K., Seierstad, I. A., in Veal, A. T. (2014): A new snow and ice load map for mechanical design of power lines in Great Britain. Cold Regions Science and Technology, 108, str. 28-35. DOI: 10.1016/j. coldregions.2014.09.001

Papler, D. (1996): Več kot 5000 gospodinjstev brez elektrike: Žled povsod po Gorenjskem trgal kable, podiral drevje in drogove. Gorenjski glas, 49(103), str. 28.
Panteli, M., in Mancarella, P. (2015): Influence of extreme weather and climate change on the resilience of power systems: Impacts and possible mitigation strategies. Electric Power Systems Research, 127, str. 259270. DOI: 10.1016/j.epsr.2015.06.012

Patt, A., Pfenniger, S., in Lilliestam, J. (2013): Vulnerability of solar energy infrastructure and output to climate change. Climatic Change, 121(1), str. 93-102. DOI: 10.1007/s10584-013-0887-0

Planton, S., Déqué, M., Chauvin, F., in Terray, L. (2008): Expected impacts of climate change on extreme climate events. Comptes Rendus Geoscience, 340(9-10), str. 564-574. DOI: 10.1016/j.crte.2008.07.009

Prawiranegara, M. (2014): Spatial multi-criteria analysis (SMCA) for basin-wide flood risk assessment as a tool in improving spatial planning and urban resilience policy making: A case study of Marikina river basin, metro Manila - Philippines. Procedia - Social and Behavioral Sciences, 135, str. 18-24. DOI: 10.1016/j.sbspro.2014.07.319

Pütz, M., Kruse, S., Casanova, E., in Butterling, M. (2011): Climate change fitness of spatial planning. Raziskovalno poročilo. Bern, ETC Alpine Space Project CLISP.

Radinja, D. (1983): Žledne ujme v Sloveniji. V: Gams, I., Orožen Adamič, M., Rupert, M., Vivod, V. (ur.): Naravne nesreče v Sloveniji kot naša ogroženost, str. 107-115. Ljubljana, Znanstvenoraziskovalni center SAZU, Geografski inštitut Antona Melika.

Rannow, S., Loibl, W., Greiving, S., Gruehna, D., in Meyer, B. C. (2010): Potential impacts of climate change in Germany - Identifying regional priorities for adaptation activities in spatial planning. Landscape and Urban Planning, 98(3-4), str. 160-171. DOI: 10.1016/j.landurbplan.2010.08.017

Rastandeh, A. (2015): Challenges and potentials in using alternative landscape futures during climate change: A literature review and survey study. Urbani izziv, 26(2), str. 83-102. DOI: 10.5379/urbani-izziv-en-2015-26-02-001

Rebula, E. (2001): Poškodbe zaradi žleda v Hrušici in Nanosu. Gozdarski vestnik, 59(3), str. 147-154.

Rebula, E. (2002): Žled v notranjskih gozdovih in njegove posledice. Ujma, 16, str. 156-166.

Resolucija o Nacionalnem energetskem programu. Uradni list Republike Slovenije, št. 57/2004. Ljubljana.

Rivera, C., in Wamsler, C. (2014): Integrating climate change adaptation, disaster risk reduction and urban planning: A review of Nicaraguan policies and regulations. International Journal of Disaster Risk Reduction, 7, str. 78-90. DOI: 10.1016/j.jijrr.2013.12.008

Rübbelke, D., in Vögele, S. (2011): Impacts of climate change on European critical infrastructures: The case of power sector. Environmental Science and Policy, 14, str. 53-63. DOI: 10.1016/j.envsci.2010.10.007

Schaeffer, R., Szklo, A. S., Lucena, A. F. P., Borba, B. S. M. C., Nogueira, L. P. P., Fleming, F. P., idr. (2012): Energy sector vulnerability to climate change: A review. Energy, 38(1), str. 1-2. DOI: 10.1016/j.energy.2011.11.056

Serrao-Neumann, S., Crick, F., Harman, B., Schuch, G., in Low Choy, D. (2015): Maximising synergies between disaster risk reduction and climate change adaptation: Potential enablers for improved planning outcomes. Environmental Science and Policy, 50, str. 46-61. DOI: 10.1016/j. envsci.2015.01.017

Sieber, M. (2013): Impacts of, and adaptation options to, extreme weather events and climate change concerning thermal power plants. Climatic Change, 121(1), str. 55-66. DOI: 10.1007/s10584-013-0915-0

Sinjur, I., Kolšek, M., Race, M., in Vertačnik, G. (2010): Žled v Slovenij januarja 2010. Gozdarski vestnik, 68(2), str. 123-130. 
Slovenski inštitut za standardizacijo (2009): Slovenski standard SIST EN 50341-3-21, Nadzemni električni vodi za izmenične napetosti nad 45 kV. Del 3-21, Nacionalno normativna določila (NNA) za državo Slovenijo (na podlagi SIST EN 50341-1:2002). Ljubljana.

Služba Vlade Republike Slovenije za podnebne spremembe (2011): Predlog zakona o podnebnih spremembah (3. osnutek). Ljubljana.

Statistični urad Republike Slovenije (2015): Odkup lesa. Dostopno na: http://pxweb.stat.si (sneto 20. 7. 2015).

Storch, H., in Downes, N. (2013): Risk management and spatial planning - understanding rapid urbanization in climate change. V: Schrenk, M., Popovich, V. V., Zeile, P, in Elisei, P. (ur.): REAL CORP 2013: Planning Times: You better keep planning or you get in deep water, for the cities they are a-changin'..., str. 1327-1333. Schwechat-Rannersdorf, Competence Center of Urban and Regional Planning.

Sudmeier-Rieux, K., Fra Paleo, U., Garschagen, M., Estrella, M., Renaud, F. G., in Jaboyedoff, M. (2015): Opportunities, incentives and challenges to risk sensitive land use planning: Lessons from Nepal, Spain and Vietnam. International Journal of Disaster Risk Reduction, 14(3), str. 205-224. DOI: 10.1016/j.ijdrr.2014.09.009

Sunyer, M. A., Madsen, H., in Ang, P. H. (2012): A comparison of different regional climate models and statistical downscaling methods for extreme rainfall estimation under climate change. Atmospheric Research, 103, str. 119-128. DOI: 10.1016/j.atmosres.2011.06.011

Sutanta, H., Rajabifard, A., in Bishop, I. D. (2010): Integrating Spatial Planning and Disaster Risk Reduction at the Local Level in the Context of Spatially Enabled Government. Prispevek je bil predstavljen na konferenci z naslovom GSDI 12 Conference, ki je potekala od 19. do 22. oktobra v Singapurju. Tipkopis.

Šifrer, M. (1977): Geografski učinki žleda v gozdovih okrog Idrije ter Postojne. Geografski zbornik, 16, str. 195-228.

Šipec, S. (1997): Pregled nesreč leta 1996. Ujma, 11, str. 7-14.

Špehar, U. (1998): Največ dela povzročil žled: kranjska območna enota zavoda za gozdove o lanskem delu. Gorenjski glas, 51(7), str. 10.

Thompson, M. P., Haas, J. R., Gilbertson-Day, J. W., Scott, J. H., Langowski, P., Bowne, E., idr. (2015): Development and application of a geospatial wildfire exposure and risk calculation tool. Environmental Modelling \& Software, 63, str. 61-72. DOI: 10.1016/j.envsoft.2014.09.018

Trontelj, M. (1997a): Kronika izrednih vremenskih dogodkov XX. stoletja: pomembni vremenski dogodki v zgodovini; vreme ob pomembnih dogodkih. Ljubljana, Hidrometeorološki zavod Republike Slovenije.

Trontelj, M. (1997b): Snegolom ob koncu leta 1995 in januarski žled. Ujma, 11, str. 46-48.

United Nations Office for Disaster Risk Reduction (2014): Terminology. Dostopno na: http://www.unisdr.org (sneto 2. 3. 2014).

United Nations Framework Convention on Climate Change (2014): Background on the UNFCCC: The international response to climate change. Dostopno na: https://unfccc.int (sneto 29. 3. 2014).

United States Environmental Protection Agency (2012a): Climate change adaptation plan: Public review draft. Dostopno na: http://epa.gov (sneto 2. 3. 2014)

United States Environmental Protection Agency (2012b): Risk assessment: Basic information. Dostopno na: http://epa.gov/riskassessment/ basicinformation.htm\#risk (sneto 2. 3. 2014).

Uprava Republike Slovenije za zaščito in reševanje (2014): Šifrant $F$ - Povprečne cene po skupinah del v elektroenergetskem omrežju. Dostopno na: http://www.sos112.si (sneto 10. 6. 2015).
Van Aalst, M. K. (2006): The impacts of climate change on the risk of natural disasters. Disasters, 30(1), str. 5-18. DOI: 10.1111/j.14679523.2006.00303.x

Wilbanks, T. J., Bhatt, V., Bilello, D. E., Bull, S. R., Eckmann, J., Horak, idr. (2008): Effects of climate change on energy production and use in the United States. Raziskovalno poročilo. Washington, D. C., Department of Energy, Office of Biological and Environmental Research.

Willems, P., Arnbjerg-Nielsen, K., Olsson, J., in Nguyen, V. T. V. (2012): Climate change impact assessment on urban rainfall extremes and urban drainage: Methods and shortcomings. Atmospheric Research, 103, str. 106-118. DOI: 10.1016/j.atmosres.2011.04.003

Wilson, E. (2006): Adapting to climate change at the local level: The spatial planning response. Local Environment, 11(6), str. 609-625. DOI: $10.1080 / 13549830600853635$

Wilson, E., in Piper, J. (2010): Spatial planning and climate change. London, Routledge.

Wiser, R., in Bolinger, M. (2014): 2013 Wind technologies market report. Springfield, U. S. Department of Energy. DOI: 10.2172/1220281

Zadnik, B. (1997): Vpliv žledenja na daljnovode. V: Pregl, M. (ur.): Jeklene konstrukcije imajo bodočnost, str. 197-206. Ljubljana, Inštitut za metalne konstrukcije.

Zadnik, B. (2006): Fenomen žleda in njegov vpliv na objekte za prenos električne energije. Ljubljana, Univerza v Ljubljani, Fakulteta za gradbeništvo in geodezijo.

Zavod za gozdove Slovenije (2014): Naravne ujme in požari večjih razsežnosti v Sloveniji. Dostopno na: http://www.zgs.si (sneto 17. 2. 2014).

Zhou, S., Mikkelsen, P. S., Halsnaes, K., in Arnbjerg-Nielsen, K. (2012): Framework for economic pluvial flood risk assessment considering climate change effects and adaptation benefits. Journal of Hydrology, 414-415, str. 539-549. DOI: 10.1016/j.jhydrol.2011.11.031 